\title{
COINCIDENTIA OPPOSITORUM E "ABSOLUTISMO CRISTOCÊNTRICO” NO PENSAMENTO POLÍTICO DE NICOLAU DE CUSA
}

\author{
Coincidentia oppositorum and the "Cristocentric Absolutism" in the Thought of \\ Nicholas of Cusa
}

\author{
William Davidans Sversutti ${ }^{1}$ \\ Pedro Calixto Ferreira Filho ${ }^{2}$
}

\begin{abstract}
RESUMO: No presente artigo, busca-se avaliar as possíveis mudanças ou continuidades do pensamento político de Nicolau de Cusa, especialmente no que diz respeito à relação entre Papa e Concílio, em dois momentos distintos de sua carreira eclesiástica e filosófica: em primeiro lugar, na obra A concordância católica (De concordantia catholica - DCC, 1433), considerada por alguns estudiosos como a suma de sua posição conciliarista e, em segundo lugar, na Carta a Rodrigo Sánchez de Arévalo (Epistola ad Rodericum Sancium de Arevalo - ERSA, 1442), considerada pelos comentadores como a melhor expressão de sua nova posição, a de um centralismo papal. A partir da avaliação dessas obras, conclui-se que, apesar de uma "mudança de partido" depois do rompimento com o Concílio de Basiléia, o pensamento político de Nicolau de Cusa é inclassificável dentre as categorias opostas "conciliarista" e "papalista". Desse modo, poderia ser considerado um "absolutismo cristocêntrico", tanto em DCC como em ERSA.
\end{abstract}

PALAVRAS-CHAVE: Filosofia política medieval; Nicolau de Cusa; Rodrigo Sánchez de Arévalo; Conciliarismo; Centralismo papal.

ABSTRACT: In this article, we seek to evaluate the possible changes or continuities of Cusanus's political thought, especially concerning the relationship between Pope and Council, in two distinct moments of his ecclesiastical and philosophical career: first, in the work The Catholic Concordance (De concordantia catholica - DCC, 1433), considered by the scholars to be the sum of his "conciliarist" position and, secondly, in the Letter to Rodrigo Sánchez de Arévalo (Epistola ad Rodericum Sancium de Arevalo - ERSA, 1442), considered by the scholars the best expression of his new "papal centralism" position. From the evaluation of these works, it is concluded that, despite a "change of party" after the break with the Basel Council, Cusanus's political thought is

\footnotetext{
1 Doutorando em filosofia pela Universidade Federal do Paraná (UFPR). E-mail: williamsversutti@gmail.com

${ }^{2}$ Doutor em filosofia pela Universidade da Sorbonne e pela Universidade de São Paulo (USP), professor de filosofia na Universidade Federal de Juiz de Fora (UFJF).). E-mail: pedro.calixto@ufjf.br

${ }^{3} \mathrm{Cf}$. tradução inédita da presente epístola no presente volume.
} 
unclassifiable among the opposing categories "conciliarist" and "papal centralism". Therefore, it could be classified as a "christocentric absolutism", both in DCC and ERSA.

KEYWORDS: Medieval political philosophy; Nicholas of Cusa; Rodrigo Sánchez de Arévalo; Conciliarism; Papalism.

O jovem canonista e filósofo Nicolau de Cusa inicia sua carreira intelectual com um relevante tratado político-eclesiástico, A concordância católica (De concordantia catholica, doravante denominada " $D C C$ " - 1433), escrito especialmente para o Concílio de Basiléia ${ }^{4}$, ocasião em que se pretendia estabelecer reformas importantes na Igreja ${ }^{5}$. Nesse tratado, alinhado aos ideais conciliaristas ${ }^{6}$, Cusa defende que o poder decisório papal advém do livre consenso e da livre eleição dos Cristãos ${ }^{7}$. Todavia, nesse momento, parece conceber uma filosofia política moderada pois, apesar de defender a superioridade

\footnotetext{
${ }^{4}$ Com o objetivo de defender a eleição de seu patrono Conde Ulrich de Manderscheid em oposição ao bispo de Tréveris, designado pelo Papa Eugênio IV, Raban de Helmstatt, Nicolau de Cusa entrou no Concílio de Basiléia em Fevereiro de 1432. Cusa, depois de perder a causa para a qual foi convocado, permanece no Concílio, trabalhando no apoio à causa contra os Hussitas e na reforma do calendário da Igreja. Cf. LEVINAS, Marcelo Leonardo; SZAPIRO, Aníbal. "El carácter histórico de la concepción cusana de verdad". Revista latino americana de filosofía, v. 37, n. 1, p. 67, 2011, p. 84. Seu tratado A concordância católica foi entregue ao Concílio em 1433. Segundo Watanabe, nessa obra, Cusa "expressa todos os princípios da teoria conciliarista e todas as demandas de seus aderentes". Watanabe considera que isso não era surpreendente, pois "Cusa, que era chanceler de Ulrich, deveria destacar a superioridade do Concílio sobre o Papa e o consentimento sobre a autoridade papal". Cf. WATANABE, Morimichi. Authority and consent in church government: Panormitanus, Aeneas Sylvius, Cusanus. Journal of the History of Ideas, v. 33 , n. 2, p. 217-236, 1972, p. 221-222. Trad. nossa. Vansteenberghe, um dos principais biógrafos de Nicolau de Cusa considera a perda do caso por parte de Cusa, o principal fator para este abandoná-lo. Cf. VANSTEENBERGHE, Edmound. Le Cardinal Nicolas de Cues 1401-1464: L'Action. La Pensée. Paris: H. Champion, 1920, p. 58.

${ }^{5}$ Sendo o primeiro Concílio Universal após Constança, Basileia representava a realização dos ideais conciliaristas. Inicialmente, suas principais decisões consistiram em decidir sobre a participação dos delegados papais na presidência do Concílio. Nesse momento inicial, o teólogo dominicano representante de Eugenio IV, João de Torquemada (não confundir com o homônimo, o inquisidor espanhol) defendia que o Concílio não tinha direito de escolher seu presidente, uma vez que o Papa tinha o direito divino instituído diretamente por Cristo de participar ou enviar comissários para representá-lo como o presidente. João de Segóvia e Jean Beaupère defendiam a posição oposta, isto é, que a plenitudo potestatis pertencia à congregatio fidelium, ou seja ao todo do "corpo dos fiéis". Dividiam o "corpus mysticum" do "corpus politicum", ou seja, o Concílio que representa o primeiro, cuja cabeça é Cristo, e a hierarquia de ofícios, que representa o segundo, cuja cabeça é o Papa. Defendem, assim, que o Concílio tem autonomia de eleger seu próprio presidente, sem o consentimento papal. Nicolau de Cusa, por sua vez, escreve o opúsculo De auctoritate presidendi, que apresenta ao Concílio oralmente, em que defende seu princípio da "concordância", que apresentará extensamente em $D C C$, entre "dois princípios aparentemente opostos: a governança da Igreja através da divinamente ordenada hierarquia dos ofícios e o consenso dos governados". Estabelecia, assim, a aceitação da representatividade do Papa no Concílio, porém, de modo restrito. Cf. BOND, H. Lawrence; CHRISTIANSON, Gerald; IZBICKI, Thomas M. Nicholas of Cusa: "On Presidential Authority in a General Council". Church history, v. 59, n. 1, p. 19-34, 1990, p. 21-22. Sobre a reação do centralismo papal ao decreto Haec Santa do Concílio de Constança, que estabelecia o poder do Concílio de decidir sem o consentimento do Papa, ver: IZBICKI, Thomas M. "Papalist reaction to the Council of Constance: Juan de Torquemada to the present". Church History, v. 55, n. 1, p. 7-20, 1986.

${ }^{6}$ Uma das ideias fundamentais desse movimento era o princípio do "consenso comum dos governados". Cf. PETRY, Ray C. Unitive Reform Principles of the Late Medieval Conciliarists. Church History, 31. June. 1962, p. 164-81, p. 172.

${ }^{7}$ Ver, por ex., De concordantia catholica, L. II, cap. XIX.
} 
do consenso do Concílio Universal ${ }^{8}$, também previa uma circunstância em que a intervenção do Papa era necessária e soberana: para se evitar um cisma ${ }^{9}$. E coincidentemente, foi essa a conjuntura política que se apresentou durante o próprio Concílio de Basiléia. Depois de um período inicial de aparente tranquilidade, suas pautas se radicalizaram e o Concílio pretendeu destituir o pontífice romano, Gabriele Condulmer (Papa Eugênio IV $)^{10}$, fomentando um novo cisma na Igreja ${ }^{11}$.

O plano de Eugênio IV de reunificação com a Igreja Oriental também foi motivo de discórdias naquele momento. Basiléia tentava reunir a si esse novo Concílio ou estabelecê-lo em Avignon, enquanto o Pontífice Romano buscava transferi-lo para a Itália, anulando as decisões de Basiléia e destituindo seus poderes. Nesse momento de conflito intenso entre o partido majoritário do Concílio e o Papa, o promissor canonista Nicolau de Cusa passa a apoiar Eugênio IV, junto de outros nomes importantes ${ }^{12}$, e se

\footnotetext{
${ }^{8}$ Ver: De concordantia catholica, L. II, caps. XII-XIV, L. III, caps. IV e XII.

${ }^{9}$ De concordantia catholica, L. II, cap. XXXIV, 259.

${ }^{10}$ Na vigésima oitava sessão, em Outubro de 1437, o Concílio declarou o Papa Eugênio IV contumaz e procedeu sua suspensão em 24 de Janeiro de 1438. Cf. WATANABE, Morimichi. Authority and consent in church government: Panormitanus, Aeneas Sylvius, Cusanus. Journal of the History of Ideas, v. 33, n. 2, 1972, p. 217-236, p. 217.

${ }^{11}$ Após o Concílio de Constança estabelecer o fim do Grande Cisma do Ocidente em 1417, elegendo o Papa Martinho V e unificando a Igreja, estabeleceu-se os polêmicos decretos: i) Haec Santa, que ditava a preeminência do Concílio Universal sobre o Papa e ii) Frequens, que postulava que um Concílio Universal deveria ser convocado a cada cinco anos. Esses decretos marcariam o período áureo do conciliarismo. Cf. LEVINAS, Marcelo Leonardo; SZAPIRO, Aníbal. "El carácter histórico de la concepción cusana de verdad". Revista latinoamericana de filosofía, v. 37, n. 1, p. 67, 2011, p. 84. Devido a uma série de fatores, dentre eles, uma grande praga, o próximo Concílio só foi convocado pelo Papa Eugênio IV, em Basiléia no ano de 1431. O relacionamento entre o Concílio e o Papa, porém, começa a ficar instável desde Dezembro de 1441, quando ele o dissolve, motivado pela abstenção de diversos bispos. Entretanto, o Papa se vê forçado a invalidar essa sua própria ordem, devido à incisiva atuação do Cardeal Cesarini que negociava a rendição dos Hussitas. O Concílio, porém, procedeu com o avanço dos ideais conciliaristas em reformar o papado e limitar seus poderes administrativos e, até mesmo, "transferir o governo central da Igreja do papado Romano a um Concílio itinerante". Cf. BLACK, Antony. Council and commune: the conciliar movement and the fifteenth-century heritage. London: Burns \& Oates, 1979, p. 56. Trad. nossa. Para desestabilizar esses avanços, o Papa concorda com os Gregos em defender um Concílio em solo italiano, na intenção de discutir a reunificação das Igrejas. Depois de um conflito a respeito do local onde seria realizado esse novo Concílio, Basiléia depôs Eugênio IV, fundamentando-se no decreto Haec Santa, e elegeu o Duque de Savoy (Félix V) como Papa, causando um novo Cisma. Isso foi o erro fatal que justificou sua dissolução, pois essa ação renegaria seus propósitos. Cf. DE GUZMAN MIROY, Jovino. Tracing Nicholas of Cusa's early development. The relationship between De concordantia catholica and De docta ignorantia. Louvain-Paris: Éditions de l'Institut Supérieur de Philosophie. 2009, p. 49.

${ }^{12}$ Nicolau de Cusa abandona o Concílio de Basileia imediatamente após a decisão do partido da maioria de escolher Avignon como sede do encontro com os gregos. Cusa já representou Eugênio IV na Dieta imperial de Frankfurt (1442), ocasião em que escreveu a ERSA. Outros nomes como Panormitanus e Nicolau de Tudeschis abandonam o partido conciliarista mais tarde e escrevem tratados em suporte às doutrinas papais, enquanto Aeneas Sylvius Piccolomini, que foi um ardente apoiador do Concílio de Basiléia, adere à corte imperial de Viena, que se mantinha neutra na disputa entre Papa e Concílio. Dentre outros nomes importantes que mudaram sua visão, estão: Giuliano Cesarini, Ludovico Pontano, Juan de Cervantes, Andrew de Escobar e Domenico Capranica. Cf. WATANABE, Morimichi. Authority and consent in church government: Panormitanus, Aeneas Sylvius, Cusanus. Journal of the History of Ideas, v. 33 , n. 2, 1972, p. 217-236, p. 217.
} 
encaminha para fazer parte de uma comitiva que viaja à Constantinopla ${ }^{13}$, na missão de firmar um acordo com os Gregos. Mais tarde, representa o Papa nas Dietas (Reichtags) da Germânia ${ }^{14}$, buscando apoio para a causa eugeniana dentre os príncipes que se mantinham neutros naquela disputa. Nesse período, Cusa ficou conhecido como o "Hércules dos eugenianos"15 e uma de suas principais vitórias foi obter o apoio de Frederico III, imperador do Sacro Império, consolidado no Concordato de Viena ${ }^{16}$. Dentre os motivos desse apoio ao Papa, pode-se supor diversos fatores: i) uma oportunidade pessoal, que impulsionaria sua carreira eclesiástica ${ }^{17}$; ii) um descontentamento com o radicalismo dos conciliaristas de Basileia $^{18}$; e, iii) a possibilidade de atuar na causa da reunião entre a Igreja Latina e a Oriental ${ }^{19}$, motivo que o próprio Cusa destaca ${ }^{20}$.

\footnotetext{
${ }^{13}$ Nessa viagem, a comitiva consegue persuadir o Imperador, o Patriarca e alguns eclesiásticos bizantinos a retornarem com eles à Veneza. Tal evento ficaria marcado na vida de Nicolau de Cusa devido à sua "experiência à beira da praia", narrada em sua Carta ao Cardeal Juliano (Nicolaus Cusanus "Epistola auctoris ad dominum Iulianum cardinalem" in: NICOLAI DE CUSA. Opera omnia, 16 vols. Vol 1, De docta ignorantia, ed. Ernst Hoffmann and Raymond Klibansky, Leipzig: Felix Meiner, 1932, p. 163, linhas 6-11), na qual, se-lhe revela a intuição do "princípio da douta ignorância", que o inspirou a escrever o seu homônimo tratado metafísico. Sobre essa experiência, ver, especialmente, o artigo de: BOYLE, Marjorie O' Rourke. Cusanus at sea: the topicality of illuminative discourse. The Journal of religion, v. 71, n. 2, 1991,p. 180-201.

${ }^{14}$ Nesse momento, segundo Izbicki (1993, p. 190), Nicolau de Cusa encontraria forte oposição dos teólogos alemães, como Ebendorfer, Bartolomeu de Maastricht e principalmente, daquele que viria a se tornar seu arqui-inimigo, o ferrenho conciliarista Johannes Wenck de Herrenberg, professor de Teologia da Universidade de Heidelberg. Sobre a relação entre Nicolau de Cusa e Wenck, consultar: HAUBST, R. Studien zu Nikolaus von Kues und Johannes Wenck aus handschriften der Vatikaneischen Bibliothek. Beiträge zur Geschichte der Philosophie und Theologie des Mittelalters, Bd. XXXVIII, Hft 1. Aschendorff, 1955.

${ }^{15}$ Apelido dado por seu amigo Aeneas Sylvius Piccolomini (De gestis concilii Basiliensis commentariorum libri II, 14-15): Hercules tamen omnium Eugeniarum Nicolaus Cusanus existimatus est [...]. Cf. WATANABE, Morimichi. Authority and consent in church government: Panormitanus, Aeneas Sylvius, Cusanus. Journal of the History of Ideas, v. 33, n. 2, p. 217-236, 1972, p. 221; BIECHLER, James. Nicholas of Cusa and the End of the Conciliar Movement: A Humanist crisis of Identity. Church History, 44, p. 521. 1975 , p. 6, nota 7.

${ }^{16}$ Cf. LEVINAS, Marcelo Leonardo; SZAPIRO, Aníbal. "El carácter histórico de la concepción cusana de verdad". Revista latinoamericana de filosofía, v. 37, n. 1, p. 67, 2011, p. 87.

${ }^{17}$ HOLLMANN, Joshua. The religious concordance. Nicholas of Cusa and Christian-Muslim Dialogue. Leiden: Brill, 2017, p. 155.

${ }^{18}$ HOLLMANN, Joshua. The religious concordance. Nicholas of Cusa and Christian-Muslim Dialogue. Leiden: Brill, 2017, p. 155.

${ }^{19} \mathrm{Tal}$ é o motivo destacado por Joseph Koch, em: KOCH, J. Nikolaus von Cues und seine Umwelt. Untersuchungen zu Cusanus-Texte IV, Briefe, Erste Sammlung in Sitzungsbchichte der Heidelberger Akademie der Wissenschaften, 1944, 1948, no 2. Heidelberg: Carl Winter, 1948, p. 20.

${ }^{20}$ Em sua Oração na Dieta de Frankfurt (1442), Nicolau de Cusa escreve: Postremo dico, quod Grecis reductis qualitercumque non potuit Basilee concilium esse universalem militantem ecclesiam representans. Cf. NIKOLAUS VON KUES, Kardinal. Writings on Church and Reform. London: Harvard University Press, 2008, p. 201.
} 
Depois dessa mudança de partido, Nicolau de Cusa não escreveu nenhum outro "tratado" político-eclesiástico em que defendesse explicitamente seu posicionamento próPapa. Nessa circunstância, Cusa muda radicalmente o foco de seus escritos para a teoria do conhecimento e a metafísica, principalmente no seminal livro A douta ignorância (De docta ignorantia, doravante denominada “DDI'-1440), dedicado ao Cardeal Cesarini. ${ }^{21}$ Algumas exegeses de seu pensamento político divergem sobre o real motivo pelo qual Cusa resolveu redirecionar seus esforços para o refinamento de sua henologia de inspiração neoplatônica ${ }^{22}$. Isbicki (1993), em seu estudo sobre a Carta a Rodrigo Sánchez de Arévalo (Epistola ad Rodericum Sancium de Arevalo, doravante denominada "ERSA" - 1442), considera que Cusa busca fundamentar uma nova identidade intelectual, de modo a demarcar-se daquela anterior de Basiléia e consolidar uma nova posição papalista dentro do quadro geral de seu pensamento. ${ }^{23}$ Biechler (1975) apresenta a tese de que aquela mudança de partido representa uma "crise de identidade" e a criação de uma nova identidade de "filósofo humanista". ${ }^{24}$ McDermott (1998), por sua vez, avalia que Cusa nunca foi um conciliarista propriamente dito. ${ }^{25}$ E outros, como Paul Sigmund (1963) e De Guzman Miroy (2009), buscam esclarecer que, apesar de reorientar sua posição política para a defesa do Papa, mudando a ênfase sobre a fonte e origem do poder decisório político-eclesiástico do consenso dos governados para o consenso do Papa, Cusa mantém uma filosofia política moderada. ${ }^{26}$

Embora os comentadores acima mencionados não reduzam o escopo da $D D I$ à questão política, reconhecem que seria nessa obra que Cusa consolida sua filosofia, de modo a também contemplar os seus ideais de uma necessária e urgente "concordância" entre os

${ }^{21}$ Sobre a relação entre Nicolau de Cusa e Cesarini na época do Concílio de Basiléia, ver: CHRISTIANSON, Gerald. Cusanus, Cesarini and the Crisis of Conciliarism. In: BOCKEN, Inigo. Conflict and reconciliation: Perspectives on Nicholas de Cusa. Leiden-Boston: Brill, 2004, p. 91-106.

${ }^{22}$ Para um estudo das influências neoplatônicas no pensamento de Nicolau de Cusa, consultar: D'AMICO, Claudia. Nicolás de Cusa em diálogo com sus fuentes: la redefinición del platonismo. Mirabilia no.19 (2014/2). Jun-Dez, 2014.

${ }^{23}$ IZBICKI, Thomas M. The Church in the Light of Learned Ignorance. Medieval Philosophy and Theology, Vol. 3 (1993): p. 187.

${ }^{24}$ BIECHLER, James. Nicholas of Cusa and the End of the Conciliar Movement: A Humanist crisis of Identity. Church History, 44, p. 5-21. 1975, p. 18-19.

${ }^{25}$ MCDERMOTT, Peter L. Nicholas of Cusa: Continuity and conciliation at the council of Basel. Church history, v. 67, n. 2, p. 254-273, 1998, p. 260.

${ }^{26}$ SIGMUND, Paul E. Nicholas of Cusa and Medieval Political Thought. Cambridge, Massachusetts: Harvard University Press, 1963, p. 279. DE GUZMAN MIROY, Jovino. Tracing Nicholas of Cusa's early development. The relationship between De concordantia catholica and De docta ignorantia. Louvain-Paris: Éditions de l'Institut Supérieur de Philosophie. 2009, p. 12; p. 199. Em certa medida, essa também é a posição de Vansteenberghe, que considera que a mudança de partido de Nicolau de Cusa "implica de sua parte menos uma modificação de natureza teórica do que uma modificação de julgamento prático." (VANSTEENBERGHE, 1920, p. 65. Trad. nossa). 
cristãos, frente às intempéries políticas que se avizinhavam: a invasão de Constantinopla e a crescente cisão interna da Igreja. As implicações políticas da "henologia" e da teoria do conhecimento expostas em $D D I$, todavia, não seriam nela discutidas explicitamente, mas somente em opúsculos imediatamente posteriores como: i) o Dialogus concludens Amedistarum errorem $(1441)^{27}$ - onde Cusa critica a posição dos “Amadeístas”, isto é, o partido da maioria em Basiléia que apoiava a eleição de Amadeu VIII (Antipapa Félix V) no lugar de Eugênio IV ${ }^{28}$; e, ii) a ERSA - escrita em 1442, no momento em que Nicolau de Cusa esperava que o canonista castelhano Rodrigo S. de Arévalo ${ }^{29}$, representante do rei Juan II na Alemanha, juntasse-se a ele na defesa de Eugênio IV na Dieta de Frankfurt, de modo a defender sua proposta de um novo Concílio contra Basiléia e Félix V. Segundo Izbicki (1993, p. 190), nesse último escrito, seria visível a sua insatisfação com os argumentos utilizados no Dialogus concludens, de modo que, na ERSA, Cusa parecia buscar uma melhor explicitação de sua filosofia política a partir do arcabouço conceitual de sua principal obra, a $D D I$.

O presente estudo pretende levantar na obra A concordância católica $(D C C)$ e na Carta a Rodrigo Sánchez de Arévalo (ERSA) as principais considerações cusanas a respeito do estatuto do poder papal e de sua relação com o Concílio, de modo a retratar aqueles dois momentos de seu percurso. Nesse intuito, apresenta-se em primeiro lugar um recorte das passagens relevantes de $D C C$ referentes à relação Papa-Concílio. Para tanto, ater-se-á ao Capítulo XXXIV do seu Livro II, onde Cusa sintetiza seu "conciliarismo moderado" e deixa claro a proposta de concordância, no intuito de harmonizar a estrutura hierárquica tradicional (o Papa como o cabeça e os demais cristãos como o corpo da Igreja) com a democracia conciliar (que, mediante o "consenso dos governados", legitima o poder papal divinamente ordenado). Em segundo lugar, passa-se à avaliação da ERSA,

\footnotetext{
${ }^{27}$ Primeiro texto de gênero dialógico composto por Nicolau de Cusa, o Dialogus concludens apresenta como interlocutores um mestre (o próprio Cusa) e um discípulo. Segundo Izbicki: "Essa requisição por uma explanação sobre a mudança da posição de seu preceptor levou a uma interpretação notavelmente benigna, para um papalista, tanto do Concílio de Constança quanto das primeiras sessões em Basiléia. A radicalização foi culpa dos retardatários [do Concílio de Basiléia]; e seus atos eram inválidos, visto que o Papa não havia com eles consentido. Esse argumento foi acoplado a uma fraca contenção, a de que Deus não permitiria que o Papa reinante prejudicasse a Igreja e a uma insistência contra aquela contenção da Providência, a de que o Papa deveria agir para edificar a Igreja. Esta última ênfase seria ser retomada na Carta a Arévalo e outros escritos de Cusa sobre a Igreja." (IZBICKI, 1993, p. 187. Trad. nossa. Grifos nossos).

${ }^{28}$ Ver: WATANABE, Morimichi; CHRISTIANSON, Gerald; IZBICKI, Thomas M. Nicholas of Cusa: a companion to his life and his times. Farnham: Ashgate, 2011, p. xxi.

${ }^{29}$ Sobre a biografia e o pensamento do canonista espanhol Rodrigo Sánchez de Arévalo, ver: TRAME, Richard H. Rodrigo Sánchez de Arevalo, 1404-1470. Spanish Diplomat and Champion of the Papacy. Washington, D.C.: The Catholic University of America Press, 1958.
} 
com especial ênfase nos conceitos de $D D I$, mobilizados para explicar a relação entre Papa e Concílio naquele escrito. Finalmente, avaliam-se quais seriam as possíveis mudanças ou continuidades de seu pensamento político naqueles dois momentos, principal pergunta que se procura responder, tendo-se em vista as demais interpretações, extraídas da literatura.

\section{Elementos de um "conciliarismo moderado" de $A$ concordância católica, $L$ II, cap. $X X X I V$}

Longe de pretender esgotar o "hercúleo" arcabouço conceitual teológico-jurídico de $D C C$, passa-se a avaliar, em linhas gerais, o posicionamento filosófico-político nela apresentado, isto é, na circunspecção do objetivo proposto, avaliam-se as especificidades de sua posição inicial "conciliarista", tendo em vista as possíveis mudanças ou continuidades de seu pensamento em relação à ERSA.

No Cap. XXXIV do Segundo Livro de DCC, Nicolau de Cusa busca recapitular e resumir as principais ideias apresentadas nos seus dois primeiros Livros. Inicia-o rememorando o tema geral de sua investigação precedente ${ }^{30}$, isto é, o princípio da concordância: a fé em um só Senhor (Cristo) em que concordam todos os múltiplos súditos $^{31}$, que é o princípio da ordenação dos diferentes membros (Papa, patriarcas e todos os cristãos) da hierarquia da Igreja, sem o qual seu "corpo" não subsiste e que promove a unidade na multiplicidade dos cristãos $^{32}$. Esse princípio tem um oposto: o cisma ou a divisão. ${ }^{33}$ Portanto, a concordância é o princípio que permite a harmonia na estruturação

\footnotetext{
${ }^{30}$ De concordantia catholica, L. II, cap. XXXIV, 247, linhas 1-2: Labor omnis praecedentis opusculi concordantiam qua subsistit ecclesia incepit ex altis et primis principiis investigare.

${ }^{31}$ De concordantia catholica, L. I, cap. I, 4, linhas 3-9: Concordantia enim est id, ratione cuius ecclesia catholica in uno et in pluribus concordat, in uno domino et pluribus subditis. Et ab uno infinitae concordantiae rege pacifico fluit illa dulcis concordantialis harmonia spiritualis gradatim et seriatim in cuncta membra subiecta et unita, ut sit unus deus omnia in omnibus.

${ }^{32}$ De concordantia catholica, L. I, cap. IV, 20, linhas 4-10: Ex quo patet papam cum patriarchis et omnibus Christianis unum tale corpus constituere, ubi sunt diversa membra et quodlibet suo officio contentum, ne totus ordo turbetur. Unde ex membrorum diversitate hierarchia comprehendi potest in ordine ad unitatem concordantiae, sine qua hierarchia non subsistit. Necesse est ergo concordiam illam esse in uno et pluribus, in uno capite et pluribus membris.

${ }^{33}$ De concordantia catholica, L. I, cap. V, linhas 1-4: Adhuc pensandum est, quoniam ecclesia ab unitate et concordantiali congregatione dicitur, quod ipsa ex fraternitate constituitur, cui nihil proprie tantum contrariatur, sicut discissio sive schisma.
} 
dos diferentes cargos hierárquicos da Igreja e a convivência das diversas opiniões dos fiéis, de modo que delas não decorra um iminente cisma. ${ }^{34}$

Nicolau de Cusa, neste momento, demonstra claramente seu "cristocentrismo": a Igreja tem por cabeça e líder absoluto Jesus Cristo ${ }^{35}$ e, portanto, é a Igreja Católica "Cristiforme" constituída por todos os espíritos racionais unidos a Cristo ${ }^{36}$, segundo diferentes graus ${ }^{37}$. Essa Igreja se constitui à imagem e semelhança de Deus, ou seja, pela imitação da "inefável concordância" verificada na Santíssima Trindade, na medida em que "a mesma é acessível ao discurso captável pelos olhos do intelecto" 38 . Unida em suas gradações hierárquicas pela concordância dos diferentes (concordantia differentiarum) ${ }^{39}$, a Igreja é semelhança da unidade-trina ${ }^{40}$. Rememora, então, do Primeiro Livro ${ }^{41}$, aquela “admirável ordem" hierárquica tradicional em que a Igreja se funda como "imagem e

\footnotetext{
${ }^{34}$ De concordantia catholica, L. I, cap. V, 27, linhas 5-6: Nam licet fides una sit funiculus colligantiae, tamen aliquando varietas opinionum absque pertinacia stat cum unitate.

${ }^{35}$ De concordantia catholica, L. II, cap. XXXIV, 247, linhas 5-7: Nulli est dubium Christum esse viam, vitam et veritatem, caput et fundamentum ecclesiae [...].

${ }^{36}$ De concordantia catholica, L. II, cap. XXXIV, 247, linhas 11-17: Quare illud corpus fidelium, in quo Christus habitabit, christiforme ecclesia catholica dicitur, in qua, sicut Christus, ita et via et veritas semper permanebit. Quomodo autem ex omnibus rationabilibus spiritibus Christo adhaerentibus ipsa universorum unica constituatur ecclesia (...).

${ }^{37}$ De concordantia catholica, L. I, cap I, 8, linhas 1-4: Unde haec est summa dicendorum, quod Christus est via, veritas et vita et omnium creaturarum caput, maritus sive sponsus ecclesiae, quae per concordantiam creaturarum omnium rationabilium ad eum unum et inter se plurium constituitur secundum varias graduationes.

${ }^{38} \mathrm{Cf}$. De concordantia catholica, L. I, cap. I, 6, linhas 1-15: Et quia manifestissimum est omne esse et vivere per concordantiam constitui, tunc in illa divina essentia, ubi vita et esse unum sunt summa aequalitate, est summa et infinita concordantia, quoniam ibi nulla contrarietas locum habere potest, ubi aeternitas vita est. Omnis autem concordantia differentiarum est. Et quanto minor contrarietas in differentiis, tanto fortior concordantia et longior vita, et ibi aeterna tunc est, ubi nulla contrarietas. Ex hac enim radice vide alta fundamenta sanctissimae trinitatis et unitatis, quoniam unitas in trinitate et trinitas in unitate, nec ulla penitus contrarietas, quia qualis pater, talis filius, talis et spiritus sanctus. Ecce inexpressibilem concordantiam in deo trino et uno, a qua quidem concordantia volenti subtilius indagare, quomodo cuncta perfectionalia de deo dicibilia aut cogitabilia in summa concordantia unius essentiae et trium personarum sunt, maxima et incomprehensibilis veritas, quae ex hoc discursu oculis intellectus obicitur, elici potest.

${ }^{39}$ Da concordantissimam unionem que se dá na fé comum, descende uma gradual diferenciação da concordância eclesiástica (gradualem differentem concordantiam ecclesiasticam) que se constitui sempre de uma concordância entre diferentes (Papa, bispos, Cardeais... etc.), ou seja, é uma concordantia differentiarum. Cf. WEILER, Anton G. Nicholas of Cusa on Harmony, Concordance, Consensus and Acceptance as Categories of Reform in the Church, in De concordantia catholica. In: BOCKEN, Inigo. Conflict and reconciliation: Perspectives on Nicholas de Cusa. Leiden-Boston: Brill, 2004, p. 79.

${ }^{40}$ Cf. De concordantia catholica, L. I, cap. V, 30,linhas 1-3; 6-9: Et in hoc exercitu Christi immortali tamquam in uno corpore concordantialis unitas fidei verae aut praesumptae graduationes differentiales requirit, de quibus amplius dicendum. [...] Unde, ut sit una continua concordantia unius sponsi et unius sponsae, necesse est in hoc primo considerare, quod tota ecclesia una est in trinitate, scilicet triumphans est et dormiens est et militans.

${ }^{41}$ De concordantia catholica, L. II, cap. XXXIV, 247, linhas 23-26: pro nostra manuductione sciatur cum diversis et ad invicem ordinatissimis huius militantis ecclesiae hierarchiis, pro modulo succincte aperui in prima huius parte, quae pars compendiosius stringi vix possit.
} 
enigma" ${ }^{42}$ da Trindade ${ }^{43}$ : i) a triunfante (a hierarquia celeste), constituída da unidade por parte de Deus, dos anjos e das almas dos santos; ii) a dormente, constituída da ordem intermediária entre os anjos e os homens ${ }^{44}$, ou seja, daqueles que morreram na fé da vida eterna e aguardam o juízo final; e, iii) a militante (a hierarquia eclesiástica), cujos membros são peregrinos na busca da união com Cristo, constituída dos sacramentos, do sacerdócio e do povo católico ${ }^{45}$.

A partir da retomada do princípio da concordância, avaliado no Primeiro Livro, Cusa busca sintetizar os objetivos do Segundo Livro, isto é, a indagação sobre os fundamentos da "primazia dos Concílios da Igreja Universal sobre toda autoridade particular de um prelado singular ou sínodo local" 46 . Para tanto, sintetiza a principal conclusão nele encontrada:

\begin{abstract}
"Se a Igreja Católica e Universal está dirigida infalivelmente pela assistência de Cristo, então, ao darse o consenso de todos os cristãos sobre uma conclusão qualquer que se inclua na necessidade de salvação da Igreja, deverá a Igreja Cristã, fiel e verdadeira, segui-la necessariamente. O verdadeiro Concílio Universal ditando tal conclusão por consenso e delegação de todos os cristãos, pela delegação de Cristo e pela inspiração do Espírito Santo, necessariamente o dita de modo verdadeiro e infalível." (NICOLÁS DE CUSA, 1987, p. 222. Trad. nossa. Grifos nossos). ${ }^{47}$
\end{abstract}

\footnotetext{
${ }^{42}$ De concordantia catholica, L. II, cap. XXXIV, 247, linhas 19-22: [...] ac insuper quomodo colligantia ipsius militantis, ubi adhuc ipsa veritas, scilicet Christus, in figura et aenigmate apprehenditur, ad ipsam veritatem facialem, quae est in patria triumphantium.

${ }^{43}$ De concordantia catholica, L. II, cap. XXXIV, 247, linhas 16-19: Quomodo autem ex omnibus rationabilibus spiritibus Christo adhaerentibus ipsa universorum unica constituatur ecclesia, ac etiam quomodo in ipsa omnium ecclesia trinitas ex eius parte triumphantium et alia militantium et tertia dormientium [...].

${ }^{44}$ De concordantia catholica, L. I, cap. V, 31, linhas 3-6: Quare dormiens ecclesia tamquam media inter angelos et homines considerata est ut umbra angelicae et militans ut umbra dormientis, licet dormiens ab humana viatrici ecclesia non separetur, quousque traducatur in triumphantem.

${ }^{45}$ De concordantia catholica, L. I, cap. VI, 32, linhas 1-13: Est autem in hoc corpore ecclesiae concordantia investiganda in signaculo trinitatis, quoniam reperiuntur tres ordines magni in una mirabili conexione ad unum caput, Christum. Primo divinissimae concordantiae trinitatis et unitatis subalternatur sacramentorum conexio. Secundo divinae concordantiae angelicae, qui sunt ministri divinae trinitatis, subalternatur sanctum sacerdotium, quoniam sacerdotes sunt ministri sacramentorum. Tertio subalternantur beatis spiritibus in patria homines fideles in via. Et sunt sacramenta illuminantia et purgantia, est sacerdotium pastorale purgatum et purgans, est fidelis populus, qui purgatur et non purgat ad instar angelicae et consequenter divinae trinitatis concordanti dispositione ordinata.

${ }^{46}$ De concordantia catholica, L. II, cap. XXXIV, 248, linhas 1-3: Post haec secunda parte difficultatem maioritatis conciliorum universae ecclesiae super omnem particularem auctoritatem singularis praesidis aut synodi localis.

${ }^{47}$ De concordantia catholica,L. II, cap. XXXIV, 248, linhas 4-11: "Si universalis catholica ecclesia infallibiliter per Christi assistentiam dirigitur, tunc concurrente omnium Christianorum consensu ad quamcumque conclusionem necessitatem salutis includentem necessario sequitur illam Christianam fidelem et veram. Universale vero concilium dictans talem conclusionem consensu et legatione omnium fidelium necessario ex Christi assistentia et sancto spiritu inspirante vere et infallibiliter dictat eandemnulla enim potest esse veritas ad aeternam salutem dirigens nisi per Christum."
} 
Como indica o excerto, Cusa exalta em DCC uma certa prioridade do Concílio Universal $^{48}$ (sua infalibilidade), enquanto locus do consenso da unidade dos Cristãos, em que a divindade se manifesta ${ }^{49}$. Em conformidade com essa conclusão, Cusa sintetiza o Segundo Livro com a afirmação segundo a qual, uma vez convocado de maneira legítima e celebrado com toda a liberdade, ao ditar uma conclusão que afete diretamente aquilo que concerne à "salvação dos fiéis", "nunca soubemos que (um tal Concílio) tivesse errado, jamais". Contrariamente, os "sínodos provinciais e até mesmo os Pontífices Romanos nunca tiveram este privilégio" 50 .

A partir dessa reflexão sobre a eminência do Concílio, Cusa afirma que, uma vez que alguns teóricos (juristas e teólogos) "modernos" exaltam a autoridade papal acima da conciliar, restaria averiguar, naquele Capítulo XXXIV, "qual seria a autoridade do Pontífice Romano”. E, em seguida, passa a definir sinteticamente a posição e a função do Papa na ordenação político-eclesiástica que propõe ao Concílio de Basiléia. É nesse passo que Cusa estabelece aquilo que aqui se define como um "conciliarismo moderado", isto é, aquela doutrina conciliarista que equilibra o poder decisório eclesiástico em duas vertentes: i) a do Papa, que herda a função de líder da Igreja por intermediário de Pedro, ou seja, detém o poder decisório mediante a vontade divina expressa na sententia petri: "Pedro, tu és pedra e sobre esta pedra edificarei a minha Igreja" (Mt. 16:18) ${ }^{51}$; e, ii) a do

\footnotetext{
${ }^{48}$ Essa superioridade era explícita no decreto Haec Santa do Concílio de Constança que estabeleceu o fim do grande Cisma: "Esse sagrado sínodo (...) declara a si mesmo tendo legitimamente reunido no Espírito Santo e compreendendo um conselho geral e representando a Igreja Católica, para deter o poder imediatamente de Cristo, ao qual todos de qualquer posição ou posição, mesmo que sejam de posição papal, são obrigados a obedecer em coisas que dizem respeito à fé, extirpação do referido cisma e reforma da referida igreja na cabeça e nos membros", citado em: BLACK, Antony. "Council and Pope: The Modern Relevance of Conciliarism." New Blackfriars 56, no. 657, p. 82-88, 1975.

${ }^{49}$ De concordantia catholica, L. II, cap. IV, 78, linhas 1-6: "Verum quia dixi, quod, si ex concordantia procedit diffinitio, tunc ex sancto spiritu processisse creditur, quoniam ipse est auctor pacis ac concordiae, et non est humanum varios homines in unum congregatos in summa libertate loquendi constitutos ex una concordantia iudicare, sed divinum, ideo praesumi hoc omnino debet."

${ }^{50}$ De concordantia catholica,L. II, cap. XXXIV, 248, linhas 11-21; 249, linhas 1-2: "Universale autem concilium ex praesidibus et legatis collectum, qui ad ipsam congregationem rei investigabilis dubio in provincia propria non digesto, dum sic in vago confluunt ad consulendum consensu subiectorum non apportato ad haec, si rite et legitime convocatum et omnibus vocatis collectum, liberrime celebratum et iuste finitum communi omnium consensu sententiam in quomodolibet salutem fidelium concernentibus dictaverit, propter propinquam repraesentationem totius catholicae ecclesiae et propter omnium fidelium consensum, qui per legatos ac praesides concurrit, numquam legimus errasse. Omnes autem provinciales synodos ac etiam Romanos pontifices hoc privilegium non attingit."

${ }^{51}$ De concordantia catholica,L. II, cap. XXXIV, 247, linhas 5-10: Nulli est dubium Christum esse viam, vitam et veritatem, caput et fundamentum ecclesiae, ad Ephesios 4 et 5 et 1 ad Corinthios 10 et in glossa super illud Matthaei 16: «Tu es Petrus, et super hanc petram», et per Augustinum in libro Retractationum, super Ioannem, in multis sermonibus ac alios multos, immo paene omnes doctores.
} 
Concílio Universal que, mediante o "consenso eletivo", é responsável por eleger e pode também destituir seu presidente, ou seja, o próprio Papa ${ }^{52}$.

Situando a posição que seu princípio político-normativo da concordância tomaria na relação Papa-Concílio que pretende fundamentar sob o prisma das Escrituras, logo no início do Cap. XXXIV, Cusa afirma sua posição:

Assim, pois, era necessário investigar qual seria a autoridade do Pontífice Romano, tanto em sua superioridade quanto na edição e promulgação dos estatutos. E, ainda que tratei de muitas coisas, contudo, firmei-me no fato de que, ainda que, segundo muitos escritos dos santos, a potestade do Pontífice advém de Deus e, segundo outros, do ser humano e dos Concílios Universais, sem dúvida, parece que, em verdade, o meio-termo da concordância é verificável nas Escrituras, e tende, por fim, a isto: que a potestade do Pontífice Romano segundo à consideração da sua proeminência, prioridade e principado, advém de Deus por meio dos seres humanos e dos Concílios, a saber, mediante o consenso eletivo. (NICOLÁS DE CUSA, 1987, p. 223. Trad. nossa. Grifos nossos). ${ }^{53}$

Em contraposição ao "conciliarismo moderado" cusano, a partir da colocação supracitada que introduz a investigação do Capítulo XXXIV, poder-se-ia considerar, por exemplo, o conciliarismo de Marsílio de Pádua (+ 1343) e o de Dietrich de Niem (+ 1418). Marsílio de Pádua, cujas teses de sua obra $O$ defensor da paz (1324) foram formalmente condenadas em $1327^{54}$, buscava derrogar quaisquer prerrogativas especiais ao papado e

\footnotetext{
${ }^{52}$ Nicolau de Cusa trata dessa questão anteriormente em: De concordantia catholica, L. II, cap. XIX, 167, linhas 1-21: "Que a liberdade de eleição é a raiz pela qual se constitui toda a potestade ordenada [...]": Si iura ac dicta sanctorum patrum, quae loquuntur nullum ad praesidentialem curam ordinari debere nisi electum ab hiis, quibus praesidere debet, servarentur, ut suae praesidentiae originem ab hiis se habere cognoscat, quibus praeest, et sic absque superbia in amore pascat, tunc videremus, quomodo ex ordinatis gradualibus electionibus ad hoc recte devenitur, quod superius per sanctum Augustinum dictum est, scilicet quod de petra, id est ecclesia fidelium, Petrus oritur. Non quod potestas praesidentialis quae in praesidentibus est a populo ortum totaliter capiat, sed, sicut praehabitum est superius, tunc sacerdotium, quod est ut anima in ecclesia militanti [...], a deo autem per sacramenta capit potestatem rationabilis animae, quae desursum venit, ut sic possit in dulci concordantia superna potestate per medium elicitae et traditae potestatis influere in corpus subiectorum, quae ad salutarem unionem cum Christo capite perficiunt.

${ }^{53}$ De concordantia catholica, L. II, cap. XXXIV, 249, linhas 11-20: Erat itaque necessarium inquirere, quae Romani pontificis auctoritas tam in superioritate quam praeceptione et statutorum editione. Et licet induxerim multa, tamen in hoc resedi quod, licet secundum plura sanctorum scripta potestas Romani pontificis a deo sit et secundum alia ab homine et conciliis universalibus, tamen videtur in veritate medium concordantiae per scripturas investigabile ad hoc demum tendere, quod ipsius pontificis Romani potestas quoad considerationem praeeminentiae, prioratus et principatus sit a deo per medium hominis et conciliorum, scilicet mediante consensu electivo.

${ }^{54}$ O Papa Clemente VI condena o conteúdo do livro O defensor da paz de Marsílio por completo, em 1343. Seus exemplares foram queimados na Universidade de Paris já em 1324. Essa obra, porém, é traduzida para o francês e, depois do Cisma do Ocidente, volta a influenciar secretamente o movimento conciliarista, embora Zabarella e Gerson, dois importantes teóricos desse movimento, negassem algumas de suas doutrinas expressamente. Seu livro circulou durante o Concílio de Basiléia e, embora nunca mencionado, acaba influenciando na radicalização de certas posições conciliaristas durante o mesmo. Cf. SIGMUND, Paul E. The influence of Marsilius of Padua on XVth-century conciliarism. Journal of the History of Ideas, v. 23 , n. 3, p. $392-402,1962$, p. 392.
} 
derivava a força coercitiva da lei totalmente da "vontade dos legisladores" "55, ou seja, excluía aquela vertente do "desígnio divino"56. E Dietrich de Niem, talvez o mais "radical" dos conciliaristas do séc. XV, ainda que muito mais moderado do que o revolucionário Marsílio, propunha reformar a Igreja no sentido de evitar abusos do papado e reuni-la a partir de um Concílio Universal. ${ }^{57}$ Dietrich de Niem, na obra De modis Uniendi et Reformandi Ecclesiam in Concilio Universali (1410), estabelecia, então, que o Papa poderia ser deposto: "desde que um anjo não pode ser Papa, segue-se que um Papa é um homem, e, como homem, é também um Papa, e, como Papa, pode pecar e, como homem, pode errar" (DIETRICH DE NIEM apud SIGMUND, 1962, p. 394. Trad. nossa). Segundo Sigmund (1962, p. 394), Dietrich havia contestado o domínio espiritual e temporal do Papa, ou seja, sua plenitudo potestatis, interpretando, na esteira de Ambrósio e Crisóstomo, a passagem escritural das "duas espadas"58 em um sentido metafórico: as mesmas representavam os Antigo e Novo Testamentos e não o poder secular e espiritual. Desse modo, Cristo não havia transferido a ninguém, nem menos a Pedro, o domínio secular e, aqueles que assim utilizavam aquela passagem: "utilizavam-nas em seu afã de usurpar o governo (...) e, sem justificação, inventar falsas interpretações das Escrituras de modo a satisfazer suas opiniões corruptas e desejos pervertidos" (DIETRICH DE NIEM apud SIGMUND, 1962, p. 394. Trad. nossa).

A teoria político-eclesiástica apresentada em $D C C$ também previa a destituição e a desobediência ao Papa em determinados $\operatorname{casos}^{59}$, porém, defendia sua soberania decisória

\footnotetext{
55 Cf. SIGMUND, Paul E. The influence of Marsilius of Padua on XVth-century conciliarism. Journal of the History of Ideas, v. 23, n. 3, p. 392-402, 1962, p. 393.

${ }^{56}$ Nicolau de Cusa critica a posição de Marsílio de Pádua (Defensor pacis, Dictio II, c. 16) que afirma que não se pode fundamentar escrituralmente a fundação da Igreja Romana por São Pedro. Cusa fundamenta sua crítica na Carta de Pedro aos Gálatas (De concordantia catholica, L. II, cap. XXXIV, 256), em que o Apóstolo se refere como se estivesse em "Babilônia", ou seja, uma referência direta de sua estadia em Roma, segundo a interpretação do cusano. Cf. SIGMUND, Paul E. The influence of Marsilius of Padua on XVth-century conciliarism. Journal of the History of Ideas, v. 23, n. 3, p. 392-402, 1962, p. 396.

${ }^{57}$ Cf. SIGMUND, Paul E. The influence of Marsilius of Padua on XVth-century conciliarism. Journal of the History of Ideas, v. 23, n. 3, p. 392-402, 1962, p. 393.

${ }^{58}$ Sobre a passagem do Evangelho de Lucas (22: 38) a respeito das "duas espadas" enquanto fundamento de algumas posições em defesa do centralismo papal, como a de Bernardo de Claraval (De consideratione, 1145) e na Bula Unam Sanctam do Papa Bonifácio VIII (1302), e da reação de alguns pensadores que a consideravam uma metáfora, como Marsílio de Pádua (Defensoris pacis, 1324) e Ockham (Breviloquium de principatu tyrannico super divina et humana, c.a. 1332), ver: MINNIS, A. J. Material Swords and Literal Lights. The status of Allegory in William of Ockham's Breviloquium on Papal Power. In: MCAULIFFE, Jana D; WALFISH, Barry D.; GOERING, Joseph W. (Eds.) With reverence for the Word. Medieval Scriptural Exegesis in Judaism, Christianity, and Islam. London: Oxford University Press, 2003.

${ }^{59}$ De concordantia catholica, L. II, cap. XVIII, 161, linhas 1-13: Quare concluditur universale concilium rite adunatum, licet graduationes inter se habere possit quoad iudicia, est tamen semper maioris auctoritatis et minoris fallibilitatis quam papae tantum. Ex quo sequitur corollarie universale concilium etiam in alio quam haeresis casu deponere posse, sicut hoc etiam de Benedicto XII et Ioanne XXIII legitur.
} 
em ocasiões específicas, regulamentadas nas leis canônicas, ou seja, sempre que coadunassem com o imperativo, divinamente instituído por Cristo, da edificação da Igreja (ad edificandum ecclesiam), numa clara diferença em relação às teorias conciliaristas supramencionadas. Um exemplo de ocasião necessária para a atuação do Papa seria a de agir soberanamente para evitar um cisma. ${ }^{60}$ Daí se considerar o conciliarismo cusano moderado, fundamentado no princípio da concordância. Ao contrário de Marsílio e Dietrich, em DCC, Cusa vê a fundamentação escritural tanto do poder decisório papal quanto do Concílio. O Concílio, através do voto, concorda em submeter-se ao poder decisório do Pontífice, sob o júdice das suas prerrogativas legais. Representando o “corpo" da "Igreja militante", o Concílio elege seu "cabeça" para que, numa unidade, os mesmos possam ascender à unidade mais perfeita: a "Igreja triunfante", da qual Cristo é o "cabeça". Em consequência, Cusa também fundamentaria um determinado poder papal via scriptura, ou seja, pela argumentação da "instituição divina". Porém, esse poder seria recebido pelo Papa mediante o consenso do Concílio Universal que, desse modo, apresentar-se-ia como aquela instância fundamental que recebia o poder "imediatamente de Cristo" à qual o Papa e a Sé apostólica seriam subordinados ${ }^{61}$.

Cusa busca avaliar, a partir desse momento ${ }^{62}$, a fundamentação escritural do primado “em graça” de Pedro. Segundo sua argumentação, uma vez que ninguém é cristão por coação, mas livremente, o poder de coação da Igreja deve fluir do "corpo místico da Igreja desde a Cabeça”, tendo-a como fonte. Cristo o distribuiu entre todos os discípulos igualmente, mas, a Pedro, segundo uma graça mais abundante ${ }^{63}$. No Evangelho de João (1: 42), Cristo diz: “tu te chamarás Cefas, que significa Pedro". No entendimento de Cusa,

Et hoc probatur ex c. 1 De renuntiatione Libro Sexto, quia si papalitas ab hoc subiecto materiali, scilicet isto homine, est iudicio ipsius papae, dum se inutilem iudicat, removibilis, ut ibidem, et hic habetur maioris auctoritatis esse concilii iudicium quam papae tantum et minus fallibile, tunc clarum est quod, sicut papa tunc potest ex causa legitima cessare ab administratione, ita etiam subiecti communi concilio possent ex eisdem causis in praestando oboedientiam cessare, quando inutiliter administraret.

${ }^{60}$ De concordantia catholica, L. II, cap. XXXIV, 259, linhas 1-18.

${ }^{61}$ De concordantia catholica, L II, cap. XVI, 148, linhas: 11-14: Quare universaliter dici potest universale concilium repraesentativum catholicae ecclesiae habere potestatem immediate a Christo et esse omni respectu tam supra papam quam sedem apostolicam.

${ }^{62}$ De concordantia catholica, L. II, cap. XXXIV, 251.

${ }^{63}$ De concordantia catholica, L. II, cap. XXXIV, 251, linhas 1-3: In hac quidem gratia dicimus quoad apostolatum omnes apostolos aequales, sicut ad ipsum sacerdotium omnes sacerdotes, sed abundantiori gratia dicimus Petrum inter apostolos primum. 
seguindo o de Agostinho, "Pedro vem de "pedra", e a "pedra" é a Igreja. Logo, no nome de Pedro, está prefigurada a Igreja" ${ }^{64}$, assunto esse que já havia tratado no Livro II:

Pedro vem de pedra e a pedra é a Igreja, que significa Cristo, porque é seu corpo místico; por isso, é patente como Cristo é a verdade, e a pedra - figura e significação de Cristo - é a Igreja, e a figura ou significação desta última é Pedro. Donde, como Cristo é a verdade, cuja figura ou significação é a pedra ou a Igreja, assim a pedra é a verdade, cuja significação e figura é Pedro. A partir disso, fica claro que a Igreja está acima de Pedro, assim como Cristo está sobre a mesma. (NICOLÁS DE CUSA, 1987, p. 140-141. Trad. nossa). ${ }^{65}$

A partir dessas colocações, fica patente seu entendimento de que tanto Pedro quanto seus sucessores estariam subordinados ao corpo místico da Igreja, que é simbolizado pela "Pedra", e que essa mesma Igreja está subordinada a Cristo, demonstrando aqui, novamente seu cristocentrismo, como avaliou-se anteriormente. Estar "subordinado a Cristo", aqui, significa que tanto os membros do Concílio quanto os Papas deveriam seguir as leis estabelecidas nos Cânones sagrados dos Concílios Universais, pois, nelas, há o consenso da totalidade dos cristãos em que a divindade de Cristo se manifesta. Essa posição revela uma priorização da comunidade sobre o papado e, nesse sentido, o Papa não estaria acima do Cânones dos Concílios Universais e não os poderia violar. ${ }^{66} \mathrm{O}$ Papa somente estaria acima daquelas leis estabelecidas por seu próprio Concílio patriarcal. Porém, em alguns casos excepcionais, o Papa deveria aplicar a "epikeia"67, de modo a intervir fora de sua jurisdição, no caso da "necessária edificação da Igreja e somente para

\footnotetext{
${ }^{64}$ De concordantia catholica, L. II, cap. XXXIV, 251. Linhas 11-12: Petrus autem a petra, petra vero ecclesia. Ergo in Petri nomine figurata est ecclesia. Cf. Agostinho, In Ioannis evangelium, tr. 7 c. 1 (PL $35,1444)$.

${ }^{65}$ De concordantia catholica, L. II, cap. XVIII, 157, linhas 32-38: Petrus a petra et petra ecclesia quae significat Christum, et propter hoc est corpus eius mysticum, ideo patet, quomodo Christus est veritas, petra - figura sive significatio Christi - ecclesia, huius autem petrae figura sive significatio Petrus. Unde sicut Christus est veritas, cuius figura et significatio est petra sive ecclesia, ita petra est veritas, cuius significatio et figura est Petrus. Ex quo clare patet ecclesiam supra Petrum esse, sicut supra illam est Christus.

${ }^{66}$ De concordantia catholica, L. II, cap. XX, 177, linhas 1-8: Ex quo apparet maioritas concilii universalis super papam et patriarchalem synodum. Sic Leo papa ad omnes episcopos per universas provincias constitutos de omnium praedecessorum suorum epistulis dicit: "Omnia decretalia constituta tam a beatae memoriae Innocentio quam aliorum omnium praedecessorum, quae de ecclesiasticis ordinibus et canonum promulgata sunt disciplinis, ita vestram dilectionem custodire debere mandamus, ut, si quis in illa commiserit, veniam sibi deinceps noverit denegari", 19 di. Si Romanorum.

${ }^{67}$ Cf. Aristóteles, Ethica nicomaqueia, 5, 10. Nicolau de Cusa, no Sermão LX, afirma: "Os moralistas gregos falam de epikeia, que é uma virtude dispensadora e interpretativa da lei, e está unida inseparavelmente à clemência do Príncipe, para que a autoridade suprema não se veja atada completamente pela lei comum". (NICOLÁS DE CUSA, 1987, p. 151-152, nota 1.)
} 
esse fim"68. Tal fim, para Cusa, é exatamente a ação daquele representante elevado ao papado no sentido de evitar um cisma:

De fato, considerando cada membro singular da Igreja singularmente e em si, então a prelatura por uma mais abundante graça, que foi necessária para abolir os cismas, lê-se que foi concedida a Pedro por Cristo, segundo a sentença de São Jerônimo, para o bom e ordenado regime da Igreja, para que ele, assim como foi o primeiro dos singulares, fosse servo e ministro de todos. Porque, se pela Igreja Pedro é assim denominado devido à pedra, e a Igreja não é senão a união dos fiéis da Igreja, a presidência se justifica devido à união dos fiéis para se evitar os cismas. Daí que a unidade dos fiéis, a que chamamos Igreja ou o Concílio Universal da Igreja Católica, está acima de seu ministro e singular presidente. (NICOLÁS DE CUSA, 1987, p. 228-229. Trad. nossa. Grifos nossos). ${ }^{69}$

Pedro é nomeado à prelatura, ou seja, ao cargo de Papa, como a "cabeça da Igreja militante" para "a execução dos mandatos de Cristo". Cusa argumenta que, nesse sentido, "todos os santos doutores afirmam que ele teve o primado, ainda que os demais sejam os vigários de Cristo", pois, "a ele foram dadas as chaves prometidas e o pastoreio mandado por aquelas palavras: “apascenta minhas ovelhas'."70 $\mathrm{O}$ "pastoreio" fora destinado a Pedro e, imediatamente após a ascensão de Cristo, o mesmo já começa a exercitá-lo e encaminhá-lo a toda a congregação dos fiéis. Desse modo, Pedro foi "o primeiro a demonstrar que possuía o vicariato de Cristo com a palavra e a doutrina e o ministério de

\footnotetext{
${ }^{68}$ De concordantia catholica, L. II, cap. XX, 169, linhas 1-13: Alio currenti dubio, an ita per decreta universalis concilii papa ligari possit, quod in contrarium non possit, facile ex praescriptis potest responderi. Quoniam, si universale concilium proprie acceptatum est supra papam, ut praedictum est, solutum est dubium. Unde, quamvis papa in c. Significasti De electione supra concilium et c.Proposuit De concessione praebendae supra iura esse se dicat, hoc est verum de concilio generali suo, ubi ut patriarcha praesidet, et de iuribus ibi aut alias in aliis particularibus conciliis vel per eum conditis, licet ob principatum super omnes de ecclesia epikeiam fatear ita sedi apostolicae alligatam, quod tolli quoad particulares casus non possit, quoniam dispensare et interpretari habeat saepe ob utilitatem et necessitatem in aedificationem ecclesiae, et solum ad illum finem.

${ }^{69}$ De concordantia catholica, L. II, cap. XXXIV, 259, linhas 1-18: Considerando vero singula ipsius ecclesiae membra singulariter et in se, tunc praelatio abundantiori gratia, quae propter tollere scisma necessaria fuit, ad bonum ecclesiae ordinatum regimen iuxta sancti Hieronymi sententiam a Christo Petro tradita legitur, ut ipse, sicut singulorum fuit primus, omnium esset servus et minister. Quoniam, si propter ecclesiam Petrus a petra dictus est, et ecclesia non est nisi unio fidelium ecclesiae, propter unionem fidelium ob tollere scisma praesidentia est. Quare unitas fidelium est illa, ad cuius servitium et observantiam praesidentia est super singulos. Hinc unitas fidelium, quam nos ecclesiam dicimus, sive universale concilium catholicae ecclesiae ipsam repraesentans est supra suum ministrum ac singularem praesidem. Et ita intelligo dictum salvatoris quod maior inter apostolos distributive debeat esse, omnium collective, quoniam sic ecclesiam faciunt, minister.

${ }^{70}$ De concordantia catholica, L. II, cap. XXXIV, 254, linhas 7-13: Unde licet omnes apostoli rectores, pastores et vicarii Christi fuere, ut in praefatione missae in cuiuslibet festivitate decantatur, tamen in pastoratu illo, rectoratu et vicariatu abundantiori gratia Petrum primatum habuisse sancti doctores affirmant per hoc, quod sibi ut ecclesiam totam repraesentanti claves promissae et datae fuere ac pastoratus praeceptus per verba: 'Pasce oves'.
} 
batizar, e também aparece como o primeiro dos Apóstolos nos Atos e no Evangelho de Lucas." ${ }^{71}$ Parafraseando São Jerônimo, Cusa coloca que:

A Igreja está fundada sobre Pedro, ainda que, em outro lugar, afirma-se que se realiza sobre todos os apóstolos e recebam todos as chaves do reino dos céus, pelo que sobre eles se funde a solidez da Igreja; mas, sem dúvida, entre os doze se elege um para que, constituída uma cabeça, se quite toda ocasião de cisma. (NICOLÁS DE CUSA, 1987, p. 226. Trad. nossa). ${ }^{72}$

Segundo esse ensinamento, Pedro "foi constituído a cabeça dos Apóstolos e nomeado seu prelado por Cristo, não obstante a Igreja estivesse fundada por igual sobre todos eles"73 e sua presença pessoal na fundação da Igreja Católica em Roma é justificada escrituralmente $^{74}$ e por autoridades como Jerônimo, Cipriano, Gregório, Ambrósio, Clemente e Agostinho. ${ }^{75}$ Essa superioridade de Pedro equivale à superioridade de um representante e deve ser entendida como "interna" ao corpo da Igreja e não "externa”, de modo que deva agir em consonância com as leis canônicas da fraternidade do Concílio Universal:

Pelo que a maioridade de Pedro não é uma maioridade exterior, mas interior à Igreja. Donde, mesmo que seja representante e cabeça dos apóstolos e propusesse algo à Igreja e em seu nome, como está no Capítulo Primeiro de Atos, e respondesse como está no Capítulo Segundo de Atos, ainda era um membro, como os outros. Por isso, ao levantar-se no meio dos fiéis, falou com reverência à mesma Igreja e admitiu ser enviado por ela à Samaria (Atos, 8). Verdadeiramente, segundo a ordem da vida verdadeira e verdade, Cristo, Senhor e nosso cabeça, todos os fiéis, que são filhos de Deus pela regeneração em Cristo, são somente irmãos, porque não há outro magistério senão o do próprio Cristo, como disse Mateus, 23: 'Não chameis nenhum de mestre (rabbi); um só é seu mestre', Cristo, 'e, portanto, todos vós sois irmãos’. Desse modo, não há senão a fraternidade de fiéis em Cristo, ainda que, nessa fraternidade, persista uma maior graça segundo a ordenação divina. (NICOLÁS DE CUSA, 1987, p. $227-228$. Trad. nossa). ${ }^{76}$

\footnotetext{
${ }^{71}$ De concordantia catholica, L. II, cap. XXXIV, 254, linhas 7-13: Illum autem pastoratum Petrus inter alios primum et principaliter sortitus immediate post Christi ascensionem incepit in omni congregatione fidelium exsecutioni demandare, sicut praesides monere et respondere solent. Unde primus fuit Petrus, qui vicariatum Christi verbo doctrinae et baptizandi officio Hierosolymis se habere ostendit et primum inter apostolos, ut in Actibus 1, 2 et 3 capitulis legitur et Lucae 6.

${ }^{72}$ De concordantia catholica, L. II, cap. XXXIV, 256, linhas 19-22: Super Petrum fundatur ecclesia, licet alio loco super omnes apostolos fiat et cuncti claves regni caelorum accipiant et ex aequo super eos ecclesiae fortitudo solidetur, tamen propterea inter unus eligitur, ut capite constituto scismatis tollatur occasio.

${ }^{73}$ De concordantia catholica, L. II, cap. XXXIV, 256, linhas 30-32: Ex qua habetur Petrum caput constitutum apostolorum et eis per Christum praelatum non obstante, quod ipsa ecclesia ex aequo super omnes apostolos sit fundata.

${ }^{74} 1$ Pe. 5: 13. Ver: De concordantia catholica, L. II, cap. XXXIV, 255.

${ }^{75}$ Sobre essa fundamentação, que excede o escopo do presente estudo, ver: De concordantia catholica, L. II, cap. XXXIV, 256, linhas 32-38.

${ }^{76}$ De concordantia catholica, L. II, cap. XXXIV, 257, linhas: 13-26: Quare illa Petri maioritas non fuit maioritas supra, sed intra ecclesiam. Unde licet os sive caput esset apostolorum ac ecclesiae et eius nomine proponeret, ut Actuum primo et responderet, ut Actuum secundo, tamen nihilominus tamquam membrum subfuit. Quare in medio fidelium surgens in reverentiam ecclesiae locutus est et passus est se mitti in Samariam ab ipsa, Actuum 8. In ordine enim ad ipsam veram vitam et veritatem, Christum, dominum et
} 
No Capítulo XXXIV do Segundo livro de DCC, o fundamento da impossibilidade de uma potestade absoluta do Pontífice parece estar no fato de que Pedro "não era mais filho de Deus que qualquer um dos santíssimos apóstolos, ainda que houvesse sido dotado de uma graça mais abundante", ${ }^{77}$ Sobre essa impossibilidade, Nicolau de Cusa lembra o Papa Gregório: "nenhum bispo pode exercer o principado da Igreja, se crê que todos seus membros se-lhes estão submetidos; assim, quem isso fizesse se faz semelhante a Lúcifer, que teve essa presunção e se esforça por colocar sua sede sozinho por sobre as estrelas do céu" ${ }^{78} \mathrm{E}$, no prosseguimento de seu raciocínio, afirma:

Considerando, pois, a cada um da mesma Igreja singularmente e em si, então a prelatura por uma mais abundante graça que foi necessária para acabar com os cismas, lê-se que foi concedida a Pedro por Cristo, segundo a sentença de São Jerônimo, para o bom e ordenado regime da Igreja, para que ele, como foi o primeiro de cada um dos singulares, fosse servo e ministro de todos. Posto que, se, pela Igreja, Pedro foi assim nomeado devido à pedra e a Igreja não é senão a união dos fiéis da Igreja, a presidência se justifica pela união dos fiéis para evitar os cismas. Daí que a unidade dos fiéis, para cujo serviço e observância serve a presidência, está acima dos singulares. Por isso, a unidade dos fiéis, que chamamos Igreja, ou Concílio Universal da Igreja Católica, está acima de seu ministro e singular residente. (NICOLÁS DE CUSA, 1987, p. 228-229). ${ }^{79}$

A presidência deve, portanto, ser moderada pela lei que emana do consenso do livre Concílio Universal. Ela adquire sua potestade para evitar os cismas e está ordenada por Deus para esse fim e nenhum poder coercitivo pode ser estabelecido sem que haja esse consenso dos governados. A fim de conservar sadio o corpo da Igreja, a "força coercitiva" consiste em "erradicar da Igreja o membro ou pé corrompido e o olho que escandaliza" 80 .

caput nostrum, omnes fideles, quia filii dei sunt per regenerationem in Christo, fratres tantum sunt, quoniam ibi non est aliud magisterium quam ipse Christus, Matthaei 23: "Nolite vocari rabbi; unus est enim magister vester", Christus, «omnes autem vos fratres estis». Unde hoc respectu non est nisi fraternitas in Christi fidelibus, licet maioritas gratiae secundum divinam ordinationem cum eadem fraternitate persistat.

${ }^{77}$ De concordantia catholica, L. II, Cap. XXXIV, 258, linhas: 3-4: Non enim erat Petrus plus filius dei quam alius ex sanctissimis apostolis, licet abundantiori gratia dotatus foret.

${ }^{78}$ De concordantia catholica, L. II, Cap. XXXIV, 258, linhas: 6-10: Eo tempore, in qua vult ostendere nullum episcopum ita principatum gerere in ecclesia quod omnia membra ecclesiae sint sibi subiecta, quin immo dicit illum Lucifero similem, qui hoc praesumit, quoniam supra astra caeli.

${ }^{79}$ De concordantia catholica, L. II, Cap. XXXIV, 259, linhas: 1-12: Considerando vero singula ipsius ecclesiae membra singulariter et in se, tunc praelatio abundantiori gratia, quae propter tollere scisma necessaria fuit, ad bonum ecclesiae ordinatum regimen iuxta sancti Hieronymi sententiam a Christo Petro tradita legitur, ut ipse, sicut singulorum fuit primus, omnium esset servus et minister. Quoniam, si propter ecclesiam Petrus a petra dictus est, et ecclesia non est nisi unio fidelium ecclesiae, propter unionem fidelium ob tollere scisma praesidentia est. Quare unitas fidelium est illa, ad cuius servitium et observantiam praesidentia est super singulos. Hinc unitas fidelium, quam nos ecclesiam dicimus, sive universale concilium catholicae ecclesiae ipsam repraesentans est supra suum ministrum ac singularem praesidem.

${ }^{80}$ De concordantia catholica, L. II, Cap. XXXIV, 261, linhas 5-6: Oportet enim membra putrida et pedem abscindi et oculum scandalizantem ab ecclesia erui, si corpus ecclesiae sanum debet conservari. Quare illa coertio $[\ldots]$. 
Essa "força coercitiva" não seria como aquela dos príncipes, mas fundada na livre aprovação dos súditos. ${ }^{81}$

Como conclusão do capítulo-resumo de suas investigações dos Livros 1 e 2 de $D C C$, Cusa considera que o principado eclesiástico (absoluto) “que está ordenado por Deus para a unidade da Igreja e para seu serviço e ministério, está constituído, na sua realidade, pela Igreja, a partir de Cristo" ${ }^{~} 2$. Desse modo, reafirma aquela sua posição moderada, que busca conciliar a posição que defende o centralismo papal "de que, na Igreja, existe somente um principado coativo proveniente de Deus" com a conciliarista "de que o mesmo principado provenha da eleição ou consenso dos homens ou da Igreja". Cusa conclui que o poder eclesiástico se equilibra na relação Papa-concílio e, "com toda verdade, pode reduzir-se a este meio da concórdia", que afirma "que toda preletora eclesiástica e espiritual foi estabelecida por Cristo mediante o consenso dos homens, ou da Igreja." 83 Nesse sentido, toda possível "deformidade" seria proveniente do fato que: "nem os presidentes usam de sua potestade ordenadamente a um fim, pelo que se justifica a presidência pastoral; nem os súditos obedecem ordenadamente aos superiores, como exige o estado de cada um" e, devido a isso, em última instância, "foi necessário se falar das leis canônicas pelas quais os santos padres conservavam a concórdia" ${ }^{84}$, isto é, dos Cânones Sagrados dos Concílios Universais que manifestam a divindade.

\footnotetext{
${ }^{81}$ De concordantia catholica, L. II, Cap. XXXIV, 261, linhas 6-24: Quare illa coertio non erit, sicut principes dominantur eorum, quia hic dominandi modus est per vim super corporibus et rebus, sed erit coertio per liberam subiectionem omnium vel partis maioris initiata et punitio non nisi ad salutem tendens. Unde ex hoc Anacletus papa et alii, ut superius continetur, dicunt Christum Petrum principem concurrente apostolorum consensu constituisse. Et sic ex subiectorum electione et consensu radicatur superioris potestas suo modo coactiva in eos. Qui enim prius liberrimi erant eligendo super se praesidem, se ei subiciunt. Unde ex hoc fundamento superius saepe dicitur potestatem coactivam aut principis aut legis ex approbatione subiectorum per se aut ad hoc communi consensu tacito vel expresso constitutum robur habere. Sic enim dicitur: "Quamquam omnis potestas desursum cf. Rom. 13,1." sit, sive coactiva sive oeconomica, regulativa et ordinativa, tamen ad hoc, ut ipsa extrinsece in actum prorumpere possit homines liberos Christianos regulando vel cogendo, tunc recta regula praerequirit subiectionem liberam eorum, cum ipsi ex lege fidei Christianae et naturali iure non artarentur extra terminos libertatis.

${ }^{82}$ De concordantia catholica, L. II, Cap. XXXIV, 264, linhas 1-3: Resideo itaque in hac conclusione quod principatus ecclesiasticus ob unitatem ecclesiae et ad eius servitium et ministerium a deo ordinatus in realitate sua a Christo per ecclesiam constituitur.

${ }^{83}$ De concordantia catholica, L. II, Cap. XXXIV, 264, linhas 3-8: Et quaecumque argumenta aut pro ea parte quod principatus coactivus a deo in ecclesia sit tantum, aut ex alia parte quod ipse coactivus principatus ex electione sive consensu hominum seu ecclesiae tantum exsistat, ad hoc medium concordantiae meo iudicio veraciter reducuntur.

${ }^{84}$ De concordantia catholica, L. II, Cap. XXXIV, 266, linhas 1-12: Et consequenter, quoniam deformitas omnis est ex hoc, quia nec praesidentes sua utuntur potestate ordinate ad finem, propter quem est pastoralis praesidentia, nec subiecti ordinate superioribus, ut status cuiusque deposcit, oboediunt, de regulis canonicis, quomodo talis concordantia per sanctos patres conservabatur, fuit dicendum.
} 


\section{A relação Papa-Concílio na Carta a Rodrigo Sanchez Arévalo}

A Carta a Rodrigo Sánchez de Arévalo (ERSA) marca um novo período na carreira eclesiástica de Nicolau de Cusa, que passa a constituir a equipe de juristas que defendem o Papa Eugênio IV. Nela, pode-se visualizar uma mudança de sua linguagem filosófica advinda, principalmente, da obra A douta ignorância (DDI). Escrita em 1442, período intermediário entre a publicação de DDI e As conjecturas $(D C)$, a ERSA parece revelar a mudança de ênfase do pensamento cusano, motivado por um conjunto de fatores, do primado do Concílio para o primado do Papado. Na ERSA, ao contrário de DCC, Cusa parece transferir a centralidade e a origem do poder eclesiástico para o Papa, pois a “contração"do ministério de Cristo se dá, em primeiro lugar, na sententia petri que estabelece o papado e, em segundo lugar, na Igreja (enquanto multiplicidade de cristãos), multiplicidade de fiéis que aceitam livremente aquela sentença. Essa transferência de origem, no entanto, deve ser compreendida a partir do aprimoramento de sua concepção cosmológica e metafísica em $D D I$. E, nesse sentido, são fundamentais as suas noções de "contração" (contractio), de complicação-explicação (complicatio-explicatio), da "coincidência dos opostos" (coincidentia oppositorum) e a de conjectura. Assim como avaliou-se todo o percurso do Capítulo XXXIV de DCC, a partir de agora, acompanha-se o percurso argumentativo utilizado por Cusa na ERSA, numa tentativa de compreender, de um lado, uma possível "mudança de ênfase" e, por outro lado, quais seriam as possíveis “continuidades teóricas" com a obra A concordância católica (DCC).

Nicolau de Cusa inicia a ERSA apresentando seu principal motivo: a relação PapaConcílio e as posições opostas naquele momento de conflito, de modo que seu destinatário pudesse "alcançar uma mais verdadeira conjectura de acordo com as regras

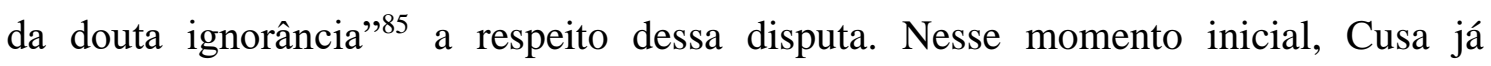
demonstra aquele mesmo cristocentrismo fundamental em DCC, porém, de modo mais profundo: o "Verbo de Deus" é o princípio cosmológico absoluto, em cuja contração (sua "entidade"), todas as coisas participam segundo uma hierarquia de maior ou menor intensidade. Desse modo, Cusa introduz uma nova noção que retrata a relação entre Deus (absoluto) e as criaturas (relativas, no domínio da alteridade), a da "complicação-

\footnotetext{
${ }^{85}$ Epistulae ad Rodericum Sancium de Arevalo, 1, linhas 5-9: Vir doctissime mihi plurimum venerande Domine Roderice de Arevalo, archidiacone de Trevino! Ad hoc, ut in his ecclesiae perturbationibus, ubi multorum opinione vulgi doctissimorum sententias in utramque partem fluctuare conspicis, ultimam veriorem coniecturam secundum regulas doctae ignorantiae venari valeas.
} 
explicação" (complicatio-explicatio) ${ }^{86}$. Primeiramente, essa noção vem formulada em seu sentido cosmológico:

[...] uma vez que todas as coisas são no Verbo de Deus, por meio do qual todas as coisas procederam ao ser -, assim, esse mesmo Verbo é complicante de todas as coisas e todas as coisas explicadas por ele na variedade da alteridade são participantes. Portanto, participam de uma forma explicativa e variada na unidade do Verbo eterno complicante de todas as coisas, de modo que o próprio Verbo, embora não possa ser participado, é participado na variedade da multidão de participantes do melhor modo que possam participar. Portanto, todas as coisas tanto [mais] são quanto mais participam da entidade do próprio Verbo. Logo, o ser de cada criatura flui dessa entidade absoluta de modo imediatíssimo, uma vez que está igualmente presente em todas as coisas; mas a alteridade das criaturas surge na alteridade dos participantes. ${ }^{87}$

Para que se possa visualizar essa sua cosmologia cristocêntrica, ou seja, a consideração de Cristo como princípio "complicante de todas as coisas", faz-se necessário rememorar uma passagem de DDI em que Cusa apresenta a conjectura $^{88}$ da complicaçãoexplicação $o^{89}$, de modo a posicionar o "Universo" (Máximo contraído) como o elemento

${ }^{86}$ A formulação clássica deste princípio se encontra em: De docta ignorantia, L. II, cap. III, 107, linhas: 14-16: Deus ergo est omnia complicans in hoc, quod omnia in eo; est omnia explicans in hoc, quod ipse in omnibus.

${ }^{87}$ Epistulae ad Rodericum Sancium de Arevalo, 1, linhas 10-21: Quoniam de papa et concilio ecclesiam repraesentante quaestio est - quod - quoniam omnia in verbo dei sunt per quod omnia in esse prodierunt tunc verbum ipsum est omnia complicans et ipsum verbum omnia explicata per ipsum in varietate alteritatis sunt participantia. Unitatem igitur aeterni verbi omnia complicantis omnia creata explicative participant, varie quidem, ut verbum ipsum, quod uti est participari nequit, in varietate multitudinis participantium meliori quidem modo quo potest participetur. Omnia igitur in tantum sunt, in quantum ipsam verbi entitatem participant. Fluit ergo esse omnis creaturae ab illa absoluta entitate immediatissime, quoniam omnibus aeque praesens est; sed in alteritate participantium exoritur alteritas creaturarum.

88 "Conjectura" é um termo técnico do pensamento cusano apresentado em seu segundo livro filosófico mais importante, As conjecturas, que busca indicar os "entes de razão" criados pela mente humana para representar a divindade infinita e irrepresentável e sua relação com as criaturas. Nessa formulação contínua de melhores representações está a missão de todo o pensamento humano, de modo que Cusa concebe que há, portanto, sempre conjecturas mais próximas da verdade, embora não haja a possibilidade, em última instância, de uma conjectura representar precisamente a verdade infinita. Na noção de conjectura, verificase a ideia de que, uma vez que o Máximo absoluto é incognoscível, "não captando a precisão da verdade tal como é, sejamos pelo menos levados a ver que existe, ela que nós não conseguimos agora compreender" (NICOLAU DE CUSA, 2003, p. 65). De docta ignorantia, L. II, prólogo, 90, linhas 4-1: Supra igitur nostram apprehensionem in quadam ignorantia nos doctos esse convenit, ut - praecisionem veritatis uti est non capientes - ad hoc saltim ducamur, ut ipsam esse videamus, quam nunc comprehendere non valemus.

${ }^{89}$ Enquanto uma conjectura humana, o par "complicação-explicação", assim como todas as conjecturas, não retrata de modo preciso o modo da divindade, pois sempre permanece no âmbito da contração e pode ser cada vez mais aperfeiçoada, ad infinitum. Dessa maneira, o modo da complicação e da explicação excede toda a mente. Cf. De docta ignorantia, L. II, cap. III, 109, linhas 29-30: Excedit autem mentem nostram modus complicationis et explicationis. E, em outro lugar, De docta ignorantia, L. II, cap. III, 111, linhas 11-16: necesse est igitur fateri te penitus et complicationem et explicationem, quomodo fiat, ignorare; hoc tantum scire, quod tu ignoras modum, licet etiam scias Deum omnium rerum complicationem et explicationem, et - ut est complicatio - omnia in ipso esse ipse, et - ut est explicatio - ipsum in omnibus esse id quod sunt, sicut veritas in imagine. O "Máximo Absoluto" supera todos os modi cognoscendi humanos: sentidos, razão e intelecto. Cf. De docta ignorantia, L. I, cap. IV, 11, linhas 6-12: Maximum, quo maius esse nequit, simpliciter et absolute cum maius sit, quam comprehendi per nos possit, quia est veritas infinita, non aliter quam incomprehensibiliter attingimus. Nam cum non sit de natura eorum, quae excedens 
de mediação entre o Máximo Absoluto (a complicação de todas as coisas) ${ }^{90}$ e as criaturas (a pluralidade dos entes-dependentes - $a b$ esse $)^{91}$, que estabelece sua relação:

\begin{abstract}
Daí que, assim como o abstrato está no concreto, assim consideramos que o máximo absoluto está primeiro no máximo contraído, para em seguida estar em todas as coisas particulares, porque ele é de modo absoluto naquilo que é tudo contraidamente. Efetivamente, Deus é a quididade absoluta do mundo ou do universo. Mas o universo é a própria quididade contraída. Contração significa, relativamente a uma coisa, o ser isto ou aquilo. Deus, pois, que é uno, é no universo uno. Mas o universo é contraidamente em todas as coisas. E assim pode entender-se como Deus, que é a unidade mais simples, existindo no universo uno, é, consequentemente, como que mediante o universo, em todas as coisas, e a pluralidade das coisas é, mediante o universo, em Deus. (NICOLAU DE CUSA, 2003, p. 82-83. Grifos nossos). ${ }^{92}$
\end{abstract}

Em DDI, a conjectura da "complicação-explicação" pretende levar o intelecto a uma intuição do modo (indizível) no qual se dá a relação entre os aspectos transcendente e imanente da divindade e de sua unidade-trina ${ }^{93}$. Ela é entendida aqui na sua aplicação cosmológica, ou seja, procura indicar o modo com que a pluralidade dos entes participa da contração do Máximo absoluto, isto é, participa do Universo, ou "macrocosmo" (uma unidade harmônica entre diferentes entes). Um ente particular contrai, em si, uma pluralidade de constituintes diferentes entre si e interrelacionados (seus membros, órgãos, etc), ao modo de um "microcosmo" que, portanto, é uma contração daquele macrocosmo.

admittunt et excessum, super omne id est, quod per nos concipi potest; omnia enim, quaecumque sensu, ratione aut intellectu apprehenduntur, intra se et ad invicem taliter differunt, quod nulla est aequalitas praecisa inter illa. Excedit igitur maxima aequalitas, quae a nullo est alia aut diversa, omnem intellectum. ${ }^{90}$ De docta ignorantia, L. II, cap. III, 105, linhas 4-11: "Nihil dici aut cogitari potest de veritate investigabili, quod in prima parte non sit complicatum. Omnia enim, quae cum eo, quod de veritate prima ibi dictum est, concordant, vera esse necesse est; cetera, quae discordant, falsa sunt. Ibi autem ostensum reperitur non posse esse nisi unum maximum omnium maximorum. Maximum autem est, cui nihil potest opponi, ubi et minimum est maximum. Unitas igitur infinita est omnium complicatio; hoc quidem dicit unitas, quae unit omnia."

${ }^{91}$ De docta ignorantia, L. II, cap. III, 110, linhas 16-18: "ut patuit in proximo capitulo, quoniam esse rei non est aliud, ut est diversa res, sed eius esse est ab esse."

${ }^{92}$ De docta ignorantia, L. II, cap. IV, 116, linhas 8-18: "Unde, sicut abstractum est in concreto, ita absolutum maximum in contracto maximo prioriter consideramus, ut sit consequenter in omnibus particularibus, quia est absolute in eo, quod est omnia contracte. Est enim Deus quidditas absoluta mundi seu universi; universum vero est ipsa quidditas contracta. Contractio dicit ad aliquid, ut ad essendum hoc vel illud. Deus igitur, qui est unus, est in uno universo; universum vero est in universis contracte. Et ita intelligi poterit, quomodo Deus, qui est unitas simplicissima, existendo in uno universo est quasi ex consequenti mediante universo in omnibus, et pluralitas rerum mediante uno universo in Deo."

${ }^{93}$ A unidade trina entre a: i) Unidade Absoluta transcendente, ii) a Unidade contraída imanente e iii) a pluralidade das coisas. Cf. De docta ignorantia, L. II, cap. VI, 124, linhas 3-7: Et ita reperimus tres universales unitates gradualiter descendentes ad particulare, in quo contrahuntur, ut sint actu ipsum. Prima absoluta unitas omnia complicat absolute, prima contracta omnia contracte. Sed ordo habet, ut absoluta unitas videatur quasi primam contractam complicare, ut per eius medium alia omnia; et contracta prima videatur secundam contractam complicare, et eius medio tertiam contractam; et secunda contracta tertiam contractam, quae est ultima universalis unitas et quarta a prima, ut eius medio in particulare deveniat. Et sic videmus, quomodo universum per gradus tres in quolibet particulari contrahitur. 


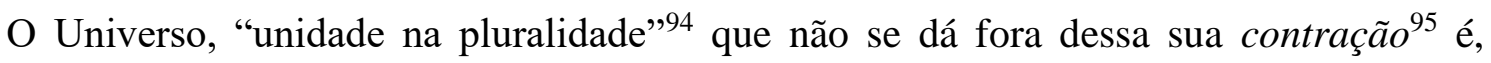
portanto, o princípio de união da e na pluralidade de entes, mediante o qual "tudo é em tudo e cada coisa é em cada coisa" ${ }^{96}$. E há, portanto, dois momentos dessa contração: o primeiro momento se dá na explicação do Máximo Absoluto no Máximo contraído (Universo) e o segundo momento na explicação do Máximo contraído na pluralidade de entes. Pensando do ponto de vista da complicação, o Universo complica a pluralidade de entes do mesmo modo que o Máximo absoluto complica o Universo. A pluralidade dos entes, portanto, participa da entidade $e^{97}$ do Máximo Absoluto transcendente, ou seja, de sua contração imanente, o Universo. Contudo, essa participação se dá mediante uma gradação, ou seja, hierarquicamente segundo uma maior ou menor "graça".

Cusa, na sequência da ERSA, coloca que todos os cristãos têm uma característica comum, que é a fé na "graça que é superadicionada à natureza", ou na salvação prometida por Jesus. E todo ser humano apresenta a capacidade de participação nessa graça divina devido à sua própria natureza racional, pois: "toda criatura racional hipostaticamente unida à divindade pela graça em Jesus Cristo pode alcançar a graça da elevação à união com Deus, que é a felicidade última." 98 Cusa, portanto, leva em consideração a particularidade irredutível de cada criatura racional singular na participação da graça

\footnotetext{
${ }^{94}$ De docta ignorantia, L. II, cap. VI, 123, linhas 3-7: Supra omnem intellectum in prioribus universum sive mundum esse comperimus unum, cuius unitas contracta est per pluralitatem, ut sit unitas in pluralitate. Et quia unitas absoluta est prima et unitas universi ab ista, erit unitas universi secunda unitas, quae in quadam pluralitate consistit.

${ }^{95}$ De docta ignorantia, L. II, cap. IV, 114, linhas 26-29: Unde unitas absoluta ab omni pluralitate absoluta est. Sed contracta unitas, quae est unum universum, licet sit unum maximum, cum sit contractum, non est a pluralitate absolutum, licet <non> sit nisi unum maximum contractum.

${ }^{96}$ De docta ignorantia, L. II, cap. IV, 117, linhas 8-18: Si acute iam dicta attendis, non erit tibi difficile videre veritatis illius Anaxagorici 'quodlibet esse in quolibet' fundamentum fortassis altius Anaxagora. Nam cum manifestum sit ex primo libro Deum ita esse in omnibus, quod omnia sunt in ipso, et nunc constet Deum quasi mediante universo esse in omnibus, hinc omnia in omnibus esse constat et quodlibet in quolibet. Universum enim quasi ordine naturae ut perfectissimum praecessit omnia, ut quodlibet in quolibet esse posset. In qualibet enim creatura universum est ipsa creatura, et ita quodlibet recipit omnia, ut in ipso sint ipsum contracte. Cum quodlibet non possit esse actu omnia, cum sit contractum, contrahit omnia, ut sint ipsum. Si igitur omnia sunt in omnibus, omnia videntur quodlibet praecedere. Non igitur omnia sunt plura, quoniam pluralitas non praecedit quodlibet. Unde omnia sine pluralitate praecesserunt quodlibet ordine naturae. Non sunt igitur plura in quolibet actu, sed omnia sine pluralitate sunt id ipsum. Foge do escopo deste artigo a avaliação pormenorizada desse princípio complexo, pelo qual Cusa passa a conceber sua "ontologia da relação", contraposta a uma "ontologia da substância". Sobre a "ontologia da relação" no pensamento Cusano, ver: ANDRÉ, João Maria. Sentido, simbolismo e interpretação no discurso filosófico de Nicolau de Cusa. Lisboa: Fundação Calouste Gulbenkian, 1997, p. 319-370.

97 Cf. Epistulae ad Rodericum Sancium de Arevalo, 1, linhas 18-19: Omnia igitur in tantum sunt, in quantum ipsam verbi entitatem participant.

${ }^{98}$ Epistulae ad Rodericum Sancium de Arevalo, 2, linhas 2-5: Nam omnis creatura rationalis, in natura humana rationali per gratiam in Christo Iesu divinitati hypostaticae unita, gratiam elevationis ad unionem dei, quae est ultima felicitas, consequi potest.
} 
infinita que é o Verbo, em que todos os redimidos participam variadamente. ${ }^{99}$ Cristo, que detém o principado sobre todas as coisas, é "a cabeça de toda a Igreja". ${ }^{100}$ E os membros da Igreja Militante depois da militância neste mundo, podem transcender àquela Igreja Triunfante (transcendente) encabeçada por Cristo e alcançar a bem-aventurança da união com Deus. Nesse sentido, a Igreja triunfante é o modelo celeste complicante da Igreja militante, que, por sua vez, é sua explicação, segundo a natureza participativa (hierárquica) desse mundo manifesto:

Essa é a Igreja na qual a graça de Jesus é explicada segundo a natureza participativa deste mundo, porque, embora o homem corruptível, pela condição de sua natureza, não possa intuir a verdade sem enigma e espelho, ao menos ele a atinge mediante o enigma ou espelho, ou [seja, pela] fé. Isso requer a graça única de Jesus Cristo, em vista da qual os fiéis ou apreendedores pela fé são peregrinantes na esperança de participar do amor unificador a seu próprio modo na variada alteridade. Apropriadamente, denominamos misticamente esta Igreja de 'o corpo de Cristo', porque em nenhuma outra a graça de Jesus Cristo é explicada, a não ser nela. ${ }^{101}$

Do mundo da participação, em que há a diferença e a alteridade e uma maior ou menor participação na graça divina, segundo Nicolau de Cusa, a verdadeira Igreja dos verdadeiros cristãos, é oculta:

De fato, assim como a Igreja Triunfante superior à razão só é acessível na simplicidade da inteligência, assim também [a Igreja] Militante [é acessível apenas] na universalidade da razão. Portanto, convém assumir no mundo sensível uma conjectura sobre esta Igreja de Cristo por meio de símbolos (signis) sensíveis, pois, de outra forma, a verdade da razão não seria atingida. De fato, esta Igreja conjectural neste mundo sensível, de acordo com a sua contraída compreensão, é a Igreja Verdadeira, embora, dentro de sua conjectura a partir de símbolos, admita tanto aqueles que recebem a Cristo em Espírito como aqueles que não. ${ }^{102}$

\footnotetext{
${ }^{99}$ Epistulae ad Rodericum Sancium de Arevalo, 2, linhas 5-9: Quapropter Iesus benedictus omnes tales beatificandos est complicans. Omnes igitur rationales creaturae non aliter quam participatione gratiae Iesu felicitatem ultimam consequuntur. In omnibus ergo gratiam ipsam participantibus est gratia varietate participantium explicata.

${ }^{100}$ Epistulae ad Rodericum Sancium de Arevalo, 2, linhas 16-18: Et haec est sancti evangelii manifestatio et divini Pauli doctrina, quoniam Christus "in omnibusin." est "principatum tenensin." et caput omnis ecclesiae."

${ }^{101}$ Epistulae ad Rodericum Sancium de Arevalo, 3, linhas 1-9: Haec quidem ecclesia est, in qua est gratia Iesu explicata secundum istius mundi participantem naturam, quia, cum non possit corruptibilis homo veritatem intueri ob suae naturae condicionem sine aenigmate et speculo, saltem ipsam in aenigmate et speculo seu fide attingat. Quapropter fideles seu in fide apprehendentes, in spe peregrinantes adhaesivo amore participare suo quidem modo in varia alteritate constat gratiam unicam Iesu Christi esse. Bene et hanc ecclesiam Christi corpus dicimus mystice quidem, quia non est nisi gratia Iesu Christi explicata.

${ }^{102}$ Epistulae ad Rodericum Sancium de Arevalo, 4, linhas 8-16: Sicut enim triumphantium ecclesia supra rationem in simplicitate intelligentiae tantum accessibilis est, ita et haec militans in rationis universalitate. Oportet autem in sensibili mundo sensibilibus signis de ipsa Christi ecclesia coniecturam sumere, cum aliter attingi nequeat rationis veritas. Quapropter coniecturalis illa ecclesia in hoc sensibili mundo secundum huius mundi contractam cognitionem vera quidem ecclesia est, licet intra suam coniecturam ex signis receptam admittat tam Christo in spiritu adhaerentes quam non.
} 
Desse modo, segundo Cusa, pode-se somente fazer uma "conjectura" de sua verdadeira constituição e hierarquia, uma vez que apenas Deus tem o conhecimento preciso de quais são os verdadeiros cristãos, na medida em que participam da graça divina mediante a caridade. Os fiéis da Igreja militante demonstram através de símbolos sensíveis sua participação na mesma, que possui símbolos sagrados para que sejam conhecidos aqueles que aceitam a Cristo. Porém, a verdadeira participação desses fiéis sempre é concebida de modo conjectural, ou seja, "na medida que os conhecimentos conjecturais podem ser obtidos a partir dos símbolos." 103 Todavia, essa Igreja foi ordenada por Cristo da melhor maneira possível através do estabelecimento de uma liderança (o papado, enquanto cargo) e de uma hierarquia descendente, ainda que possa haver desvios na conduta cristã desses líderes, devido às suas imperfeições. Esse, no entanto, é o melhor modo de organização possível:

Portanto, digo que esta Igreja de Cristo, julgada desse modo conjectural, é considerada santa, mesmo que maus e hipócritas se misturem sob os símbolos sagrados, símbolos esses que são sagrados até onde [as conjecturas] atingem. Portanto, essa Igreja não contém todos os que aderem a Cristo. Aqueles que não manifestaram nenhum sinal sensível, permanecem excluídos deste juízo. Do mesmo modo, nem todos os desta Igreja aderem a Cristo, que admite apenas o bem da união. Porém, como a condição desta vida é tal que a Igreja deva ser assim, não hesitamos [em dizer] que foi ordenada por Cristo da melhor maneira que pode ser. ${ }^{104}$

Desse modo, para que a Igreja Militante espelhe a Trindade, ou seja, para que seja perfeita a seu modo, precisa de uma cabeça "sensível", que é Pedro, que recebe de Cristo através da sententia petri a missão de unir a Igreja Militante em torno de si. Em Pedro, a Igreja existe de modo complicado, pois é o primeiro e único confessor de Cristo dentre os homens e, por isso:

[...] através da confissão da "Pedra" que é Cristo, [Cristo] explicou a Igreja complicada em si mesmo pelo Verbo da doutrina primeiramente a Pedro, que [dela] recebe seu nome. Portanto, não há outra Igreja senão a que teve seu início a partir de Pedro através da revelação celestial, que é a união dos fiéis em

\footnotetext{
${ }^{103}$ Epistulae ad Rodericum Sancium de Arevalo, 5, linhas 3-6: Quapropter haec ipsa ecclesia sacra quaedam habet signa ad hoc instituta, ut per ea cognoscamus eos qui Christi sunt eo quidem modo, quo ex signis coniecturalis trahi cognitio potest.

${ }^{104}$ Epistulae ad Rodericum Sancium de Arevalo, 5, linhas 6-15: Dico igitur quod haec ecclesia Christi huius coniecturalis modi iudicio sancta censetur, etiamsi mali et ficti sub signis sacris se intermisceant, quorum signa tantum quae sacra sunt attingit. Non igitur omnes Christo adhaerentes includit haec ecclesia. Qui enim nullo sensibili signo manifesti fiunt, penitus hoc iudicio exclusi remanent. Sic nec omnes de hac ecclesia Christo adhaerent, qui bonos tantum ad unionem admittit. Quoniam autem huius vitae condicio talis est quod hanc ecclesiam ita sse oportet, ipsam a Christo meliori quidem modo, quo ipsa ut sic ordinari potuit, ordinatam non haesitamus.
} 
torno da confissão de Pedro. Segue-se que a explicação de Pedro, que leva o nome da Pedra complicante da Igreja, é uma Igreja Una participante da mesma confissão na alteridade da multidão de crentes. ${ }^{105}$

Nesse passo, percebe-se claramente aquelas duas explicações do poder divino que é retratada na $D D I$ em dois movimentos, acima discutidos, de modo que a Igreja, da mesma forma, recebe a contração do poder de Cristo, cabeça da Igreja Triunfante, primeiramente em Pedro, e depois na Igreja Una que se consiste na alteridade da multidão de crentes. Essa seria uma conjectura da organização política eclesiástica que busca simbolizar a ordem cósmica do melhor modo possível. Da mesma forma que o Máximo absoluto se explica no máximo contraído, o ministério de Cristo se explica em Pedro. E, da mesma forma que o Máximo contraído se explica na pluralidade dos entes, Pedro se explica na "alteridade da multidão de crentes". Isso se dá devido à união dos crentes em torno da “confissão da Pedra". A multidão de crentes, complicada na "Pedra" que é Cristo, explicase mediante Pedro. Ou seja, mediante a "confissão da Pedra", a alteridade de crentes participa da Igreja (Triunfante) que é Cristo, unidade absoluta. Assim, em cada membro da Igreja militante deve haver a livre aceitação dessa sentença, de modo que o mesmo possa participar da Igreja, ou seja, ela se torna o objeto do livre consenso dos cristãos. Essa participação, na continuidade da ERSA é descrita da seguinte forma:

\begin{abstract}
Por isso, é necessária a existência de vários membros de um único corpo da Igreja, nos quais exista aquela confissão toda no todo e em cada parte dela. Segue-se que a unidade da Igreja existe na diversidade variada. E, assim como a força da unidade não pode ser participada a não ser na alteridade, a força do princípio complicante não pode ser apreendida a não ser nos principiados explicados. Não se atinge a força da natureza do pai complicante Adão de outro modo, a não ser nos homens explicados a partir dele; do mesmo modo, tampouco [a força] do Criador [é atingida], a não ser nas suas criaturas. Portanto, segundo o modo mencionado acima, a força complicativa de Pedro, cabeça da Igreja, não pode ser apreendida exceto na Igreja explicada a partir dele. ${ }^{106}$
\end{abstract}

\footnotetext{
${ }^{105}$ Epistulae ad Rodericum Sancium de Arevalo, 6, linhas 4-13: In quo est haec ipsa ecclesia complicative ut in primo uno confessore Christi. Petrum autem primum Christi confessorem scimus inter homines. Et ob hoc Petrus, a confessione petrae quae Christus est nomen accipiens, complicatam in se ecclesiam explicavit verbo doctrinae primo omnium. Non est igitur aliud ecclesia, quae a Petro initium cepit superna revelatione, quam unio fidelium in Petri confessione. Explicatio igitur Petri a petra dicti ecclesiam complicantis est ecclesia una eandem confessionem in alteritate multitudinis credentium participantis.

${ }^{106}$ Epistulae ad Rodericum Sancium de Arevalo, 7, linhas 1-12: Quoniam autem multitudo unitatem non nisi in varia alteritate potest participare, non potuit ecclesia nisi in varia participatione unitatis subsistere. Quapropter varia esse membra unius corporis ecclesiae necesse fuit, in quibus una illa confessio tota in toto et in qualibet eius parte exsisteret. Unitas igitur in varia alteritate ecclesia exsistit. Et sicut unitatis virtus non nisi in participata alteritate attingi potest, sic nec complicantis principii virtus aliter quam in explicatis principiatis potest apprehendi. Non enim virtus unitatis naturae Adae complicantis patris aliter quam in explicatis a se hominibus attingitur; sic nec creatoris nisi in ipsis creaturis. Hoc igitur modo Petri, capitis ecclesiae huius, complicativa virtus non nisi in explicata a se ecclesia potest apprehendi.
} 
A força complicativa de Pedro, assim como a do Universo em $D D I$, não existe fora da multiplicidade de cristãos que é a Igreja, ou seja, ele não está "acima" dela. O principado de Pedro só faz sentido dentro da Igreja. Sua unidade existe, portanto, explicada na Igreja, ou seja, instanciada em sua hierarquia e o poder absoluto ou plenitudo potestatis não é localizado nem em Pedro, nem em qualquer um dos prelados, mas em Cristo:

\begin{abstract}
Não há unidade explicável na multidão, a não ser que a força da unidade exista de modo maior, complicado. Sabemos deste principado universal, originalmente complicante de cada principado particular, que o mesmo é inexaurível multiplicação de [principados] particulares. Portanto, se os poderes dos patriarcas, arcebispos, metropolitanos, bispos e presbíteros está na Igreja, seus [poderes] devem ser contraídos. Entretanto, o contraído não se origina a partir de si mesmo, mas depende do absoluto. Segue-se que o poder do primeiro e supremo contém em sua plenitude todos os poderes de todos os outros; assim, não há poder exceto um, o do primeiro, que é participado de vários modos na alteridade dos prelados, porém, ao máximo, por nenhum; Imparticipável é Aquele que é. ${ }^{107}$
\end{abstract}

O poder de nenhum dos membros do corpo da Igreja e tampouco do conjunto dos membros é absoluto, ou máximo, pois todos eles participam da contração do "Imparticipável” segundo variados modos, ou seja, do poder contraído primeiro por Pedro, e depois explicado na unidade dos diferentes membros da Igreja. O poder de cada um desses membros é participar da unidade da Igreja, mediante a unidade em torno de Pedro (submetendo-se à sententia petri) e, desse modo, o poder de cada um deles é contraído. O principado na Igreja é, portanto, "absoluto a seu modo", ou seja, contraidamente $^{108}$. E todo o poder que descende aos outros cargos da hierarquia descende do poder contraído do papado.

O Poder absoluto, que pode ser concebido conjecturalmente mediante o princípio da “coincidência dos opostos" (coincidentia oppositorum), isto é, aquele máximo que "é tudo aquilo que pode ser"109 supera infinitamente o poder mundano ${ }^{110}$. Neste mundo da

\footnotetext{
${ }^{107}$ Epistulae ad Rodericum Sancium de Arevalo, 8, linhas 6-18: Non enim est unitas in multitudine explicabilis, quoniam unitatis virtus complicative maior exsistat. Hinc principatum universalem, omnem particularem principatum originaliter complicantem, inexhauribilem multiplicatione particularium cognoscimus. Si igitur in ecclesia est patriarcharum, archiepiscoporum, metropolitanorum, episcoporum presbyterorumque potestas, has quidem contractas esse constat. Contractum autem ex se ortum non habet, sed ex absoluto dependet. Quare potestas primi et supremi in sua plenitudine ambit omnem omnium potestatem; immo non est potestas nisi una et primi, quae in alteritate rectorum varie participatur, a nullo tamen maxime; imparticipabilis enim est uti est.

${ }^{108}$ Epistulae ad Rodericum Sancium de Arevalo, 9, 8-9: Principatus enim in hac ecclesia absolutus quidem est suo modo, quoniam in ipso ecclesia complicatu.

${ }^{109}$ De docta ignorantia, L. I, cap. IV, 11, linhas 12-16: [...] quare maximum absolute cum sit omne id, quod esse potest, est penitus in actu; et sicut non potest esse maius, eadem ratione nec minus, cum sit omne id, quod esse potest. Minimum autem est, quo minus esse non potest. Et quoniam maximum est huiusmodi, manifestum est minimum maximo coincidere.

${ }^{110}$ Epistulae ad Rodericum Sancium de Arevalo, 10, 11-13: Vides coincidentiam in unitate universalis potestatis, differentes spirituales et temporales potestates in ecclesia distincte explicatas.
} 
contração, porém, aplicar-se-ia o "princípio da não-contradição": o Papa, sucessor de Pedro, não pode ser príncipe e súdito ao mesmo tempo, pois “é das leis soluto e não pode ser condenado pelos súditos"111, o que, segundo Cusa, seria irracional: a respeito do mundo da contração, "de fato, a razão não admite a coincidência dos contraditórios." 112 O Papa, portanto, internamente à Igreja tem uma função e um cargo específico que obedece a um princípio, o da edificação da Igreja. Caso o mesmo não o obedeça, esse não seria o principado da Igreja:

[...] o sagrado príncipe universal existe para edificar a Igreja. Por essa razão, todo principado seja espiritual ou temporal, desde que se submeta a esse fim, é possível na Igreja. E, na medida em que resiste a esse fim, não é principado na Igreja, pois não participa da única potestade eclesiástica universal que, em todo poder que está na Igreja, é tudo aquilo que este [poder] é, contraidamente. ${ }^{113}$

O novo cisma executado por Basiléia incorreu, portanto, em um crime contra o ordenamento eclesiástico rompendo com a sua unidade sem um motivo justo, previsto nos Cânones, pois o Papa Eugênio IV, em nenhum momento, agiu contra a unidade da Igreja. Ao contrário, buscava a unidade entre os Latinos e os Gregos no momento em que essa mais se fazia necessária e, assim, deveria ter sido obedecido. Caso houvesse erro em sua decisão, a solução seria não obedecê-lo e, se houvesse dúvidas sobre suas ações, a decisão deveria sempre ser pró-Papa. Nunca, de um possível erro, derivar outro cisma:

Se, no entanto, houver dúvida e a intenção do príncipe não for clara, deve-se presumir do príncipe sagrado que [ele] usou corretamente o poder a ele confiado; e [o mesmo] deve ser obedecido. Logo, com isso, entendamos que, na Igreja, onde existem pessoas boas e más, o príncipe sagrado pode ser bom ou mau e vejamos que seu poder não pode se opor à Igreja, pois, nas coisas que não estão complicadas nessa sua potestade, ninguém está sujeito a ele, e [vejamos] que não há perigo em obedecer em questões duvidosas, mas grande perigo em não obedecer: sobre tudo isso, Agostinho diz que nenhuma causa pode se dar, pela qual é necessário iniciar um cisma. Por esse motivo, haver um cisma é um crime diabólico e imperdoável. ${ }^{114}$

${ }^{111}$ Epistulae ad Rodericum Sancium de Arevalo, 9, 14-15: Item quidam sapientissimi intellexerunt, qui principem solutum legibus et non posse a subditis iudicari dixerunt.

${ }^{112}$ Epistulae ad Rodericum Sancium de Arevalo, 9, 14-15: Ratio enim contradictoriorum coincidentiam non admittit.

${ }^{113}$ Epistulae ad Rodericum Sancium de Arevalo, 10, 5-13: Nam principatus universalis ad aedificandam ecclesiam exsistit. Quare omnis principatus sive spiritualis sive temporalis, in quantum huic fini subservit, in ecclesia esse potest. Et in quantum huic fini resistit, non est principatus in ecclesia, cum non participet unicam ecclesiasticam universalem potestatem, quae in omni potestate, quae in ecclesia est, est id quod est ipsa contracte.

${ }^{114}$ Epistulae ad Rodericum Sancium de Arevalo, 11, 8-17: Si vero dubium foret et de mente principis constaret, pro principe praesumendum quod recte potestate utatur, et sibi oboediendum est. Cum ergo intelligamus in ecclesia, ubi sunt boni et mali, principem etiam posse et bonum et malum esse et videamus potestatem eius ecclesiae obesse non posse, cum in his, quae in ipsa potestate non complicantur, ei non subsit quisquam, et in dubiis oboediendo nihil sit periculi, sed periculum magnum non oboediendo: hinc ait Augustinus nullam posse causam dari, ob quam necessarium sit ad schisma pervenire. Quare schisma diabolicum inexcusabile crimen exsistit. 
O Papa, portanto, na edificação da Igreja, não poderia permitir que revoltados iniciassem um cisma e destruíssem a sua unidade, sujeita a seu comando: isso seria abolir a ordem e o status ecclesia. Alguns poderiam argumentar que os Papas não possuem o mesmo poder de Pedro e, por isso, poderiam dividir a Igreja mediante um cisma, mas isso seria refutado na medida em que abolir a ordem é exatamente aquilo que significa "não seguir Pedro" ${ }^{115}$. O Papa tem um poder contraído ou específico, destinado a manter essa ordem e, portanto, deve agir para evitar o cisma. Todos os prelados que derivam do poder de Pedro têm o mesmo poder de Pedro, menos a contração. ${ }^{116}$ Assim, o Papa não poderia agir sobre os demais prelados em situação contrária, onde os mesmos observam a contração daquele mesmo poder, ou seja, em uma situação em que mantivessem a ordem e a integridade do corpo da Igreja. ${ }^{117}$

Para coibir a possibilidade do erro dos Papas, existe um "ordenamento de estatutos e outras regras universais". ${ }^{118}$ No entanto, em situações extraordinárias como a possibilidade de um cisma, o próprio Pontífice estaria autorizado a, visando a unidade e o bem comum da Igreja, "discernir uma dispensação (epikeia) ou mudança útil em prol da edificação da Igreja" e, nesse sentido não pode ser reprimida pelos prelados subordinados a ele nesse poder divinamente instituído:

Da mesma forma, os mais sábios sempre entenderam que - embora a mão do sagrado príncipe estendida para edificar a Igreja não possa ser inibida ou impedida por nenhuma observância ou regra dos padres, mesmo nos Concílios -, no entanto, não há nele um livre poder de rejeitar, ainda que uma só vez, o poder explicado por Pedro e saudavelmente ordenado em prol do regimento da Igreja, desde que [a Igreja] requeira a sua ajuda na edificação. Mas nada é mais oportuno do que executar apropriadamente o que foi testamentado inviolavelmente pelos santos padres daquilo que [convém] ao verdadeiro sucessor de Pedro nas coisas que procedem da potestade explicadora de Pedro, do mesmo modo. ${ }^{119}$

\footnotetext{
${ }^{115}$ Epistulae ad Rodericum Sancium de Arevalo, 12, 19-21: Nam tollere ordinem et statum universalis ecclesiae explicare non est sequi Petrum.

${ }^{116}$ Epistulae ad Rodericum Sancium de Arevalo, 12, 1-5: Adverte pater, quomodo - explicata ecclesia primitiva et contracta ipsa universali Petri potestate varie secundum varias particulares superintendentias - quilibet rector in sua particularitate Petri potestatem contracte participans eandem - salva contractione - quam Petrus habet potestatem.

${ }^{117}$ Epistulae ad Rodericum Sancium de Arevalo, 12, 9-15: Ita scilicet quod ipse, qui est universalis Petri successor, in particularem Petri successorem non habeat potestatem, per quam potestas aedificatoria particularis in sibi subiectis immutationem capiat aut impediatur. Secus autem, quando superintendit princeps universalis, ne rector credita potestate in aedificationem abutatur in destructionem subiectae ecclesiae.

${ }^{118}$ Epistulae ad Rodericum Sancium de Arevalo, 13, 9-10: [...] sive illae sint regulae sive ordo statuum aut alia universalia [...].

119 Epistulae ad Rodericum Sancium de Arevalo, 13, 13-22: Eo quidem modo sapientiores semper intellexerunt quod - quamvis principis ecclesiae manus ad aedificationem extensae nulla observantia aut regula patrum, etiam in conciliis inhiberi prohiberique possent-non est tamen apud ipsum libera potestas reiciendi semel per Petri explicatam potestatem salubriter pro regimine ecclesiae ordinata, quamdiu illa ad aedificationem praestans adiumentum. Sed nullam sedem magis oportet sanctorum patrum bene statuta
} 
Ao contrário, quando o mesmo excede a força de seu poder instituído, ou seja, promove algo que vai contra os estatutos como, por exemplo, quando "não motivado por razão de utilidade ou necessidade mas por causa particular indigna”, deve-se adotar a desobediência, mas nunca o cisma. Caso o mesmo persistir obstinadamente nesse erro que desune a Igreja:

Por essa razão não seria inconveniente, se ele persistisse obstinadamente, [que] a Igreja pudesse dele se afastar, quando o mesmo se afastou daquela unidade da Igreja, sem a qual a Igreja nada é [e], disso, não se infere um cisma. Desse modo, aquele pontífice é entendido como sujeito aos cânones dos santos padres, como se nele não houvesse poder de abusar de acordo com seu desejo das coisas bem ordenadas e, se nisso ele persistisse obstinadamente, confirmar-se-ia indigno do principado que menoscaba com esse seu abuso. De algum modo, Pedro vive no seu sucessor universal e, nos cânones patrísticos, [vivem] os próprios padres, e a Igreja universal, nos padres; assim, diz-se que Pedro vive na Igreja nas regras dos santos padres, desde que [as mesmas] prestam auxílio no propósito de edificação da Igreja. ${ }^{120}$

Concluindo seu raciocínio no fim de ERSA, Cusa evoca a regra da douta ignorância para avaliar a relação conjectural entre Pontífice e a Igreja, de modo a imitar a complicação-explicação naquele sentido cosmológico: a Igreja está no pontífice complicadamente e o pontífice, igualmente, explicado na Igreja, isto é, segundo uma clara contração do poder absoluto e, portanto, segundo uma modalização: somente quando o mesmo guarda suas sacras ordenações de modo adequado. ${ }^{121}$ Isso permite a Cusa reconhecer conjecturalmente que:

[...] Nosso santíssimo senhor não pode ser proibido por qualquer ordenança de qualquer sínodo, quando o Concílio em prol da reunião com a Igreja Oriental [está] em pauta, naquela agenda em que tal assunto era o mais congruente; e ele ordenou que dissolveria todas as outras congregações nesse propósito; e dispensou os padres da Basiléia, para que pudessem concordar livremente com tão santa união. Pois, assim como não há potestade pontifícia para a destruição dos atos convenientes dos padres, assim também não há poder sob o céu que possa diminuir sua autoridade, quanto menos para resgatar os dissidentes do covil. Esses homens obcecadíssimos de espírito furioso são tidos como insensatos - e néscios -, quando reivindicaram para si algum tipo de poder judicial sobre o príncipe da Igreja e lhe dirigiram uma hórrida ofensa, separando-se perniciosíssimamente dele e da Igreja Católica universal por todo o mundo. ${ }^{122}$

inviolabiliter exsequi, tamquam verum Petri successorem in his, quae ex eadem Petri potestate explicatorie prodiere.

120 Epistulae ad Rodericum Sancium de Arevalo, 14, 5-16: Quapropter non esset inconveniens, si pertinaciter in hoc persisteret, ab eo recedi posse per ecclesiam, quando recessus ipse unitati ecclesiae, sine qua ecclesia esse nequit, scissuram non inferre[n]t. Eo quidem modo pontificem canonibus sanctorum patrum subesse intelligendum est, quasi in eo non sit potestas bene ordinatis pro libito abutendi et, si in hoc pertinaciter persisteret, quod tunc se principatu, quem in abusu parvifaceret, indignum constitueret. Quemadmodum enim Petrus in universali successore vivit, ita et in canonibus patrum, quoniam patres ipsi et universa ecclesia in patribus; sic et Petrus in ecclesia in ipsis sanctorum regulis vivere dicitur, quamdiu utilitati aedificandae ecclesiae praestant adiumentum.

${ }^{121}$ Epistulae ad Rodericum Sancium de Arevalo, 15, 2-4: [...] in pontifice esse ecclesiam complicative et ipsum esse pariter in ecclesia, hoc est cum ipsa in suis sacris ordinationibus consentanee vigilare.

${ }^{122}$ Epistulae ad Rodericum Sancium de Arevalo, 15, 6-19: Videaturque quam aperte sanctissimum dominum nostrum nulla cuiuscumque synodi constitutione prohiberi potuisse quod conilium pro reductione 
Rodrigo de Sánchez Arévalo deveria, portanto, unir-se à defesa da posição papalista naquela disputa, devido tanto à correção das atitudes do Papa em relação aos Cânones na sua atribuição específica da santa unificação da Igreja (no caso, com os Gregos), quanto aos motivos práticos que ameaçavam o Ocidente cristão ou seja, às "pressões diárias dos Sarracenos",de modo que os mesmos "não sejam tolerados sob algum perigosa conveniência por aqueles que procuram, por um ato temerário, abater com anátema o vigário de Cristo." 123

\section{Conclusão}

Avaliado brevemente o percurso do Capítulo XXXIV do Segundo livro de DCC, em que alguns aspectos de um possível "conciliarismo moderado" de Nicolau de Cusa foram abordados e os principais tópicos da relação Papa-Concílio em ERSA, dois escritos que marcam períodos importantes na carreira eclesiástica de Nicolau de Cusa, notou-se que uma grande semelhança se dá na maioria de suas posições. As mudanças parecem advir das variações entre suas linguagens.

Considera-se como a principal semelhança e continuidade entre os dois escritos avaliados o fato de que Cusa não atribui o poder absoluto a nenhum dos dois lados da disputa: nem ao Concílio e nem ao Papa. Esse poder absoluto, segundo nosso autor, convém somente a Cristo. Desse modo, em DCC e ERSA, Nicolau de Cusa oferece um "absolutismo cristocêntrico" como princípio político. Cusa considera, desse modo, no domínio do mundo criado, ou da contração, um poder relativo que sempre é equilibrado pelas leis canônicas, nas quais se manifesta Cristo. Assim, caso se desejasse classificar a posição inicial de Nicolau de Cusa como "conciliarista", esta seria melhor considerada como "moderada". O mesmo cabe à sua posterior posição "papalista". Em ambas,

\footnotetext{
Orientalis ecclesiae in eo loco, ubi magis rebus agendis congruebat, non constitueret atque ob hoc omnes alias congregationes dissolveret et patres a Basilea absolveret, ut ad tam sanctam unionem libere concurrere possent. Nam sicut non est potestas pontificis ad destructionem bene actorum per patres, ita nec est potestas sub caelo, quae eius posset auctoritatem minuere, quo minus errantes ad ovile reducat. Visi sunt illi obcaecatissimi viri in spiritu furoris fuisse extra omnem sensum, quando sibi supra principem ecclesiae - nescio qualem - iudiciariam vindicabant potestatem et horridum nefas attentaverunt in principem suum saevientes, se ipsos ab eodem et universa per orbem catholica ecclesia perniciosissime secantes.

${ }^{123}$ Epistulae ad Rodericum Sancium de Arevalo, 16, 2-4: Regi in quotidiana Agarenorum depressione infestius diatim occurrat quam tales christianae rei publicae inimicissimos sub quadam periculosa coniventia tolerari per eos, quos ipsi temerario ausu cum Christi vicario anathemate ferire conati sunt.
} 
portanto, deve-se sempre observar as leis dos santos padres como fatores restritivos e, nesse sentido, a sua "mudança de lado" parece ser apenas aparente.

Uma substancial "mudança" poderia ser argumentada nas questões: i) da interpretação cusana do "consenso" entre os cristãos; e, ii) da relação de subordinação do Papa à unidade da Igreja em DCC. Em DCC, o consenso se apresenta de forma ampla e abstrata: ele se dá em relação às leis que "tratam da salvação". Mas, em ERSA, essa lei é especificada: o consenso de todos os cristãos consiste em aceitar a sententiapetri, que estabelece o Papa como cabeça da Igreja militante, de modo a espelhar a ordem cósmica que possui o Universo como mediação entre Deus e a pluralidade dos entes. Desse modo, o Papa, em ERSA, equivale à figura do "Universo" em DDI. Em DCC, é a Igreja que ocupa esse lugar de mediação. Porém, ao se avaliar a passagem em que Cusa trabalha a interpretação da sententia petri em $D C C$, percebe-se que o fato de Pedro ser "subordinado" à pedra que é a unidade da Igreja e a Cristo não parece mudar substancialmente em ERSA. Pode-se, por exemplo, interpretar que a "subordinação" do Papa em $D C C$ equivaleria à "segunda contração" de ERSA, ou seja, aquela contração de "Pedro" na "multidão dos crentes", da qual o mesmo não pode ser desvinculado, assim como o Universo da pluralidade de entes em $D D I$. E, também não se pode excluir a interpretação de que, em $D C C$, as leis que "tratam da salvação" incluam a sententia petri, mais enfatizada em ERSA.

Por outro lado, o que mais se destaca é que, uma vez que, segundo a consideração cusana sobre as conjecturas, nenhuma opinião deste mundo seria capaz de retratar a verdade absoluta de modo preciso. Ambas as caracterizações contrárias de seu pensamento: ou "papalista", ou "absolutismo papalista" ou "conciliarista", ou "absolutismo conciliarista", teriam suas limitações e reduziriam o pensamento do autor. Talvez, nem ao menos o qualificativo "moderado", a elas adicionado, conseguiria retratálas absolutamente, pois, mesmo que a "lei" apareça como esse elemento de moderação, uma vez que nos Cânones sagrados alguns autores defendem a superioridade do Concílio e outros a do Papa, deve-se considerar, segundo o contexto, que ambas podem ser válidas em dado momento. Uma dessas situações se dá quando o Papa decide algo errado, ou seja, que vai contra o bem comum da Igreja. Nesse caso, o Concílio deve sobressair ao Papa e tanto desobedecê-lo quanto destituí-lo, caso o mesmo persista em seu erro. Nessa situação, o Concílio é contraidamente superior. Porém, quando há dúvida em determinadas situações e quando está certo, deve-se sempre obedecê-lo e, nessas outras situações, maiores em número, o Papa é contraidamente superior. Tanto em $D C C$, quanto 
em ERSA, considera-se, portanto, que o Papa possui uma superioridade relativa: na linguagem de ERSA, "contraída"; na linguagem de $D C C$, segundo uma "graça mais abundante". Em ambas, essa superioridade se deve à ordem instituída por Cristo na sententia petri e deve obedecer à regra ad edificandum ecclesiam. Assim, uma vez que nem o poder do Concílio, nem o do Papa é absoluto, ambos devem agir tendo em perspectiva a unidade ao invés da divisão. O Papa, porém, possui a maior graça da "dispensação" (epikeia). Contudo, em ambos os escritos, essa sua maior "graça" é circunscrita ao serviço da Igreja, pois o Papa somente deve utilizá-la para evitar um cisma e promover a unidade.

E, uma vez que ambos possuem em dada ocasião a superioridade, poder-se-ia considerar que Nicolau de Cusa não é: i) nem papalista; ii) nem conciliarista; iii) nem papalista $e$ conciliarista; e, iv) nem papalista ou conciliarista. Essa quádrupla negação dos opostos é uma das conjecturas preferidas por Cusa para retratar o absoluto. ${ }^{124}$ Localizando o poder no Absoluto transcendente, Cusa não poderia afirmar precisamente, pela regra da douta ignorância, qual das posições opostas é superior. Poderia, no entanto, fornecer uma conjectura. No âmbito da contração, as conjecturas participam mais ou menos do absoluto segundo sua capacidade. No entanto, elas participam do absoluto, ou seja, participam na alteridade conjectural. Em outras palavras, é impossível igualar em sua perfeição a ordem da Igreja Triunfante com as pessoas imperfeitas que pertencem à Igreja Militante. Porém, deve-se conjecturar que o modelo deixado por Cristo na sententia petri é, nesse sentido, uma melhor posição do que a defesa de um cisma, proposta de Basiléia. Ela é a "melhor" conjectura, pois participa num maior grau da Unidade absoluta. E isso já se revelava em DCC no Capítulo XXXIV do Segundo Livro. Se há, portanto, na teoria política cusana um princípio fundamental, esse é a unidade da Igreja, imensamente desejada em sua época. A unidade tem, em seu pensamento, uma prioridade ontológica em relação à pluralidade. Retirada-a, nada resta.

Ao considerar-se, finalmente, a posição dos diversos exegetas de sua posição política, percebe-se que as classificações que se baseiam em algum daqueles opostos, bem como as que propõem que haja uma "mudança de posição" nos dois escritos, são como "conjecturas" menos perfeitas do que as "conjecturas" dos que admitem uma passagem de uma posição "conciliarista moderada", para uma "papalista" também "moderada". No entanto, essas duas posições moderadas poderiam ser consideradas diferentes? Entende-

${ }^{124}$ Cf. De coniecturis, I, V, 21. 
se que não, apesar da mudança do vocabulário utilizado em ERSA. Nesse sentido, próximos estudos podem esclarecer se Cusa compõe a metafísica de $D D I$ a partir de ideias que já visualizava em $D C C$.

Conclui-se, portanto, que o "absolutismo cristocêntrico" cusano, presente tanto em DCC quanto em ERSA tem a intenção proposital de ser inclassificável em "categorias" políticas opostas, o que é compreensível a partir da própria teoria do conhecimento de Nicolau de Cusa. Pois é justamente na superação das oposições teóricas fundadas no princípio de não-contradição que seus princípios da concordância e da coincidência dos opostos seriam capazes de propor um caminho alternativo para o fim dos conflitos de sua época e para a tão desejada unidade política da cristandade.

\section{Referências}

ANDRÉ, João Maria. Sentido, simbolismo e interpretação no discurso filosófico de Nicolau de Cusa. Lisboa: Fundação Calouste Gulbenkian, 1997.

BIECHLER, James. Nicholas of Cusa and the End of the Conciliar Movement: A Humanist crisis of Identity. Church History, 44, p. 5-21. 1975.

BLACK, Antony. Council and commune: the conciliar movement and the fifteenthcentury heritage. London: Burns \& Oates, 1979.

BLACK, Antony. "Council and Pope: The Modern Relevance of Conciliarism." New Blackfriars 56, no. 657, p. 82-88, 1975.

BOCKEN, Inigo. Conflict and reconciliation: Perspectives on Nicholas de Cusa. LeidenBoston: Brill, 2004.

BOND, H. Lawrence; CHRISTIANSON, Gerald; IZBICKI, Thomas M. Nicholas of Cusa: "On Presidential Authority in a General Council”. Church history, v. 59, n. 1, 1990, p. 19-34.

BOYLE, Marjorie O.'Rourke. Cusanus at sea: the topicality of illuminative discourse. The Journal of religion, v. 71, n. 2, 1991, p. 180-201.

CHRISTIANSON, Gerald. Cusanus, Cesarini and the Crisis of Conciliarism. In: BOCKEN, Inigo. Conflict and reconciliation: Perspectives on Nicholas de Cusa, LeidenBoston: Brill, 2004, p. 91-106.

D'AMICO, Claudia. Nicolás de Cusa em diálogo com sus fuentes: la redefinición del platonismo. Mirabilia no. 19 (2014/2). Jun-Dez, 2014. 
DE GUZMAN MIROY, Jovino. Tracing Nicholas of Cusa's early development. The relationship between De concordantia catholica and De docta ignorantia. Louvain-Paris: Éditions de 1'Institut Supérieur de Philosophie, 2009.

HAUBST, R. Studien zu Nikolaus von Kues und Johannes Wenck aus handschriften der Vatikaneischen Bibliothek. Beiträge zur Geschichte der Philosophie und Theologie des Mittelalters, Bd. XXXVIII, Hft 1. Aschendorff, 1955.

HOLLMANN, Joshua. The religious concordance. Nicholas of Cusa and ChristianMuslim Dialogue. Leiden: Brill, 2017.

IZBICKI, Thomas M. "The Church in the Light of Learned Ignorance". Medieval Philosophy and Theology, Vol. 3 (1993): p. 187.

IZBICKI, Thomas M. "Papalist reaction to the Council of Constance: Juan de Torquemada to the present". Church History, v. 55, n. 1, p. 7-20, 1986.

$\mathrm{KOCH}, \mathrm{J}$. Nikolaus von Cues und seine Umwelt. Untersuchungen zu Cusanus-Texte IV, Briefe, Erste Sammlung in Sitzungsbchichte der Heidelberger Akademie der Wissenschaften, 1944, 1948, no 2. Heidelberg: Carl Winter, 1948.

LEVINAS, Marcelo Leonardo; SZAPIRO, Aníbal. "El carácter histórico de la concepción cusana de verdad". Revista latinoamericana de filosofía, v. 37, n. 1, p. 67, 2011.

MCDERMOTT, Peter L. Nicholas of Cusa: Continuity and conciliation at the council of Basel. Church history, v. 67, n. 2, p. 254-273, 1998.

MINNIS, A. J. Material Swords and Literal Lights. The status of Allegory in William of Ockham's Breviloquium on Papal Power. In: MCAULIFFE, Jana D; WALFISH, Barry D.; GOERING, Joseph W. (Eds.) With reverence for the Word. Medieval Scriptural Exegesis in Judaism, Christianity, and Islam. London: Oxford University Press, 2003.

MCAULIFFE, Jana D; WALFISH, Barry D.; GOERING, Joseph W. (Eds.) With reverence for the Word. Medieval Scriptural Exegesis in Judaism, Christianity, and Islam. London: Oxford University Press, 2003.

NICOLAI DE CUSA. Opera omnia, 16 vols. Vol 1, De docta ignorantia, ed. Ernst Hoffmann and Raymond Klibansky. Leipzig: Felix Meiner, 1932.

NICOLÁS DE CUSA. De concordantia catholica, o sobre la unión de los católicos. Introducción y traducción de Jose M. de Alejandro Lueiro, S. J. Madrid: Centro de Estudios Constitucionales, 1987.

NICOLAU DE CUSA. A douta ignorância. Tradução, introdução e notas de João Maria André. Baseada na edição bilíngue da Academia de Heidelberg na Felix Meiner Verlag. Lisboa: Fundação Calouste Gulbenkian, 2003.

NIKOLAUS VON KUES, Kardinal. Writings on Church and Reform. London: Harvard University Press, 2008. 
SIGMUND, Paul E. Nicholas of Cusa and Medieval Political Thought. Cambridge, Massachusetts: Harvard University Press, 1963.

SIGMUND, Paul E. The influence of Marsilius of Padua on XVth-century conciliarism. Journal of the History of Ideas, v. 23, n. 3, 1962, p. 392-402.

TRAME, Richard H. Rodrigo Sánchez de Arevalo, 1404-1470. Spanish Diplomat and Champion of the Papacy. Washington, D.C.: The Catholic University of America Press, 1958.

VANSTEENBERGHE, Edmound. Le Cardinal Nicolas de Cues 1401-1464: L'Action, La Pensée. Paris: H. Champion, 1920.

WATANABE, Morimichi. Authority and consent in church government: Panormitanus, Aeneas Sylvius, Cusanus. Journal of the History of Ideas, v. 33, n. 2, p. 217-236, 1972.

WATANABE, Morimichi; CHRISTIANSON, Gerald; IZBICKI, Thomas M. Nicholas of Cusa: a companion to his life and his times. Farnham: Ashgate, 2011.

WEILER, Anton G. Nicholas of Cusa on Harmony, Concordance, Consensus and Acceptance as Categories of Reform in the Church, in De concordantia catholica. In: BOCKEN, Inigo. Conflict and reconciliation: Perspectives on Nicholas de Cusa. LeidenBoston: Brill, 2004, p. 77-90. 